\title{
Cladistics
}

\section{Phylogenetic analysis of host-symbiont specificity and codivergence in bioluminescent symbioses}

\author{
Paul V. Dunlap ${ }^{\mathrm{a}, *}$, Jennifer C. Ast ${ }^{\mathrm{a}}$, Seishi Kimura ${ }^{\mathrm{b}}$, Atsushi Fukui ${ }^{\mathrm{c}}$, Tetsuo Yoshino ${ }^{\mathrm{d}}$ and \\ Hiromitsu Endo
}

${ }^{a}$ Department of Ecology and Evolutionary Biology, University of Michigan, Ann Arbor, Michigan, USA; ${ }^{b}$ Fisheries Research Laboratory, Mie University, Shima, Mie, Japan; ${ }^{c}$ School of Fisheries and Marine Technology, Tokai University, Shimizu-Orido, Shizuoka, Japan; ${ }^{d}$ Department of Marine Sciences, University of the Ryukyus, Nishihara, Okinawa, Japan; ${ }^{e}$ Laboratory of Marine Biology, Kochi University, Kochi, Japan

Accepted 3 January 2007

\begin{abstract}
Several groups of marine fishes and squids form mutualistic bioluminescent symbioses with luminous bacteria. The dependence of the animal on its symbiont for light production, the animal's specialized anatomical adaptations for harboring bacteria and controlling light emission, and the host family bacterial species specificity characteristic of these associations suggest that bioluminescent symbioses are tightly coupled associations that might involve coevolutionary interactions. Consistent with this possibility, evidence of parallel cladogenesis has been reported for squid-bacterial associations. However, genetic adaptations in the bacteria necessary for and specific to symbiosis have not been identified, and unlike obligate endosymbiotic associations in which the bacteria are transferred vertically, bacterially bioluminescent hosts acquire their light-organ symbionts from the environment with each new host generation. These contrasting observations led us to test the hypotheses of species specificity and codivergence in bioluminescent symbioses, using an extensive sampling of naturally formed associations. Thirty-five species of fish in seven teleost families (Chlorophthalmidae, Macrouridae, Moridae, Trachichthyidae, Monocentridae, Acropomatidae, Leiognathidae) and their light-organ bacteria were examined. Phylogenetic analysis of a taxonomically broad sampling of associations was based on mitochondrial 16S rRNA and cytochrome oxidase I gene sequences for the fish and on $\operatorname{rec} A, \operatorname{gyr} B$ and $l u x A$ sequences for bacteria isolated from the light organs of these specimens. In a fine-scale test focused on Leiognathidae, phylogenetic analysis was based also on histone $\mathrm{H} 3$ subunit and 28S rRNA gene sequences for the fish and on $\operatorname{gyr} B, \operatorname{lux} A, \operatorname{lux} B, \operatorname{lux} F$ and $\operatorname{lux} E$ sequences for the bacteria. Deep divergences were revealed among the fishes, and clear resolution was obtained between clades of the bacteria. In several associations, bacterial species identities contradicted strict host family bacterial species specificity. Furthermore, the fish and bacterial phylogenies exhibited no meaningful topological congruence; evolutionary divergence of host fishes was not matched by a similar pattern of diversification in the symbiotic bacteria. Re-analysis of data reported for squids and their luminous bacteria also revealed no convincing evidence of codivergence. These results refute the hypothesis of strict host family bacterial species specificity and the hypothesis of codivergence in bioluminescent symbioses.
\end{abstract}

(c) The Willi Hennig Society 2007.

Members of several families of marine fishes and squids establish mutualistic associations with luminous bacteria, called bioluminescent symbioses (Herring and Morin, 1978; Hastings and Nealson, 1981; Dunlap and Kita-Tsukamoto, 2006). In these associations, the animal forms a complex of tissues called a light organ, in

\footnotetext{
*Corresponding author: E-mail address: pvdunlap@umich.edu
}

which typically a single species of light-producing bacteria is cultured extracellularly, along with accessory tissues that control, direct and diffuse the bacterial light from the animal's body. The animal uses the bacterial light in various luminescence displays that are associated with sex-specific signaling, predator avoidance, locating or attracting prey, and schooling (Hastings, 1971; Morin et al., 1975; McFall-Ngai and Dunlap, 1983; McFall-Ngai and Morin, 1991; McFall-Ngai, 1991; Woodland et al., 2002; Sasaki et al., 2003; Jones and 
Nishiguchi, 2004; Sparks et al., 2005). In turn, the bacteria use nutrients obtained from the host to reproduce (e.g., Nealson, 1979; Graf and Ruby, 1998) and are disseminated from the animal's light organ into the environment (Haygood et al., 1984; Nealson et al., 1984; Ruby and Asato, 1993).

Along with the animal's ecological dependence on bacterial light and its specialized anatomical adaptations for harboring bacteria and controlling light emission, several other features of bioluminescent symbioses suggest they are tightly coupled associations that might involve coevolutionary interactions (Nealson et al., 1981; Saffo, 2002). One such feature is their apparent specificity. Members of a given family of bacterially luminous fishes or squids are thought to consistently harbor the same species of luminous bacteria in their light organs (Reichelt et al., 1977; Ruby and Morin, 1978; Hastings and Nealson, 1981; Dunlap and KitaTsukamoto, 2006; Dunlap and Ast, 2005). This "host family bacterial species specificity" is believed to result from the host animal selecting its species of symbiotic bacteria and doing so with sufficient specificity that other kinds of bacteria are prevented from colonizing its light organ (Reichelt et al., 1977). Colonization efficiency of the "native" (i.e., specific) symbiont over other bacteria in experimental colonization studies (e.g., McFall-Ngai and Ruby, 1991; Fidopiastis et al., 1998) supports the concepts of species specificity and host selection, which presumably would have a genetic basis. A strict symbiont-host specificity, resulting from genetically based host selection of the symbiont, presumably could provide opportunities for coevolutionary events, although such reciprocal heritable changes (Page and Charleston, 1998) may be difficult to identify. Hostsymbiont codivergence (i.e., cospeciation; Page and Charleston, 1998), a possible consequence of coevolution, however, may be easier to detect. Indeed, data indicating host-symbiont "parallel evolution" for the luminous bacterium Vibrio fischeri colonizing light organs of sepiolid squids have been reported (Nishiguchi et al., 1998). These data have been interpreted as evidence of coevolution in bioluminescent symbioses (Thompson, 2005), although genetic adaptations in the bacteria necessary for and specific to light-organ symbiosis have not been identified.

In contrast to this view, other features of bioluminescent symbioses distinguish this class of symbiosis in fundamental ways from bacterial-animal endosymbioses. Endosymbioses are mutually obligate associations in which the intracellular symbiotic bacteria are maternally transferred and are generally assumed to involve coevolutionary interactions (e.g., Cary and Giovanonni, 1993; Baumann et al., 1995; Peek et al., 1998; Lo et al., 2003; Hosokawa et al., 2006). One major difference with endosymbioses is that in most bioluminescent associations, the luminous bacteria, which are extracellular, are not obligately dependent on the host for their reproduction; they colonize a variety of other marine habitats, including intestinal tracts, skin and body fluids of marine animals, sediment, and seawater, where they coexist and successfully compete with many other kinds of bacteria as members of commensal, saprophytic, pathogenic, and free-living bacterial communities. A second major difference is that light-organ symbiotic bacteria are acquired from the environment with each new generation of the host (Wei and Young, 1989; McFall-Ngai and Ruby, 1991; Wada et al., 1999); that is, they are acquired horizontally instead of being transferred vertically through the maternal inheritance mechanisms seen for obligate bacterial endosymbionts of terrestrial and marine invertebrates (e.g., Cary and Giovanonni, 1993; Baumann et al., 1995; Peek et al., 1998; Hosokawa et al., 2006). Furthermore, the substantial genomic diversity among strains of luminous bacteria populating individual light organs indicates that colonization of fish light organs is effected by multiple, genetically distinct strains, not by a single, specific strain type (Dunlap et al., 2004; Dunlap and Ast, 2005). A related difference is that the strict hostsymbiont specificity expected for associations undergoing coevolutionary change may not consistently characterize light-organ symbioses; certain squids and fishes harbor two species of bacteria in their light organs (Fidopiastis et al., 1998; Nishiguchi, 2000; Kaeding et al., 2007). Because the bacteria are facultative, apparently opportunistic symbionts, selection for symbiosis-specific genetic changes in the bacteria seem less likely than they would be for obligate, maternally transferred endosymbionts.

These different views led us to examine the issues of specificity and codivergence in bioluminescent symbioses. Our goals were to define the fidelity of host family bacterial species specificity in naturally occurring associations and test the extent of host-symbiont codivergence. For this work, we carried out an extensive sampling of bioluminescent associations, isolated and identified the light-organ bacteria specific to each host using phylogenetic criteria, and tested for host-symbiont phylogenetic congruence. We also reanalyzed data and results for bacteria symbiotic with sepiolid squids, using parsimony and cophylogeny mapping.

\section{Materials and methods}

\section{Collection of fish specimens}

Fishes were collected from coastal and bentho-pelagic waters in various locations in Japan, Okinawa, Taiwan, and the Philippines (Fig. 1; Table 1). Collection efforts focused on local and regional fish markets where a variety of shallow- and deep-dwelling fishes are landed. 


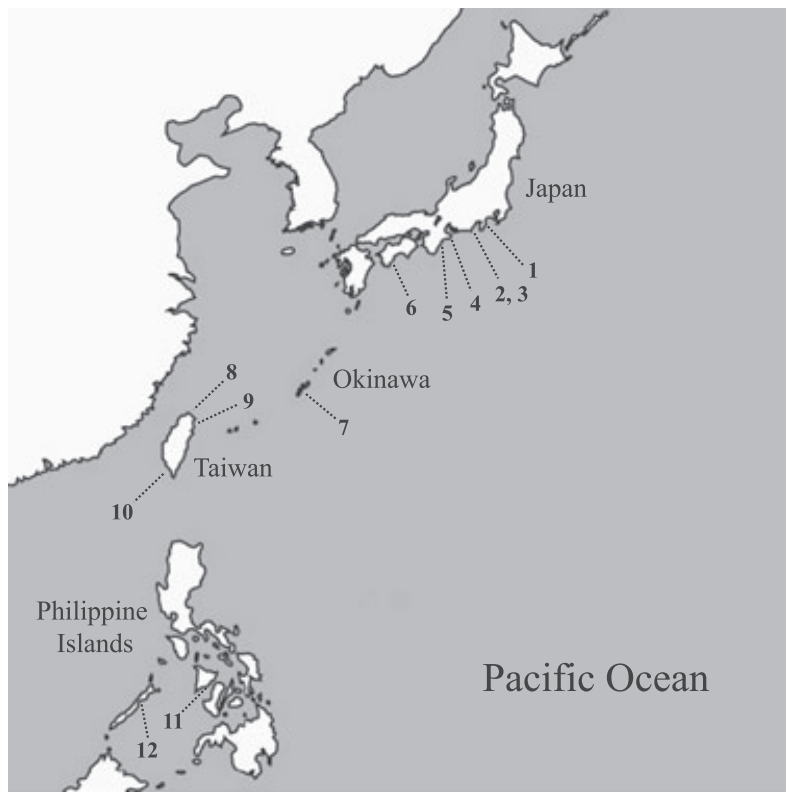

Fig. 1. Locations in Japan, Okinawa, Taiwan and the Philippine Islands where bacterially bioluminescent fishes were collected. Numbers indicate the specific collection location or fish market: (1) Odawara City Fish Market, sampling Sagami Bay; (2) Suruga Bay, deep-water trawls; (3) Numazu City Fish Market, sampling Suruga Bay; (4) Wagu Fish Market, sampling the Shima-hanto area; (5) Owase City Fish Market, sampling the Kumano Sea; (6) Saga Fish Market, sampling Tosa Bay; (7) Awase, Okinawa, sampling Nakagusuku Bay; (8) Taipei City Fish Market, sampling the East China Sea; (9) Dahsi Fish Market, sampling the northern portion of the Philippine Sea; (10) Tungkang Fish Market, sampling the northern portion of the Philippine Sea; (11) Tigbauan and Iloilo, Panay, Philippines, sampling the Visayan Sea; and (12) Palawan, Philippines, sampling the Sulu Sea.

Fish specimens were kept chilled until excision of flank muscle tissue and removal of the light organ, generally within $1-2 \mathrm{~h}$ from the time of collection. Fishes were identified to species by reference to Nakabo (2002), Kimura et al. (2003) and Sparks et al. (2005). Ichthyological nomenclature follows Nelson (2006), Shimizu (1997) and Sparks et al. (2005). Fish specimen designations follow Dunlap et al. (2004).

Samples for mitochondrial DNA extraction were flank muscle tissue, which was excised free of skin and stored in $90 \%$ ethanol at $-20{ }^{\circ} \mathrm{C}$. DNA was extracted from small chunks of the tissue using the Qiagen QIAquick Tissue Extraction Kit (Qiagen Corp., Valencia, CA), according to the manufacturer's protocol.

\section{Isolation of bacterial strains}

Bacteria were isolated from the light organs of fishes essentially as previously described (Dunlap, 1985; Ast and Dunlap, 2005; Dunlap and Ast, 2005). The light organ was aseptically dissected from the fish and homogenized in $0.5 \mathrm{~mL}$ or $1.0 \mathrm{~mL}$ of sterile artificial $70 \%$ seawater containing $25 \mathrm{~mm}$ HEPES buffer
(pH 7.25) (BSW-70) in a sterile hand-held Ten Broeck tissue grinder. The light organ homogenate was then serially diluted in BSW-70, and portions of one or more of the end dilutions were spread on plates of LSW-70 agar, which contained per liter $10 \mathrm{~g}$ tryptone, $5 \mathrm{~g}$ yeast extract, $350 \mathrm{~mL}$ double-strength artificial seawater (Nealson, 1978), $650 \mathrm{~mL}$ de-ionized water, and $15 \mathrm{~g}$ agar. Dilutions of light-organ homogenates, generally to $10^{-5}$, and plating volumes, generally $25-100 \mu \mathrm{L}$, were based on a typical light-organ population size of approximately $10^{8}$ cells (Dunlap, 1984). Plates were incubated for $18-24 \mathrm{~h}$ at room temperature (typically $18-27{ }^{\circ} \mathrm{C}$, depending on season, location and availability of air conditioning). This plating procedure typically gave rise to approximately 50-300 well-isolated luminous colonies per plate. Non-luminous colonies were not observed. Single colonies (i.e., individual strains) were then picked at random from the plates, stabbed into individual vials containing LSW-70 agar, returned to the home laboratory, purified on LSW-70 agar plates, grown overnight with shaking in LSW-70 broth, and stored as frozen, viable cultures at $-75^{\circ} \mathrm{C}$ in cryoprotective medium (Dunlap and Kita-Tsukamoto, 2006). Bacterial strain designations report the host fish species and specimen number of this laboratory (Dunlap et al., 2004); e.g., chubb.1.2 designates strain number 2 from specimen number 1 of Caelorinchus hubbsi. Genomic DNA was purified from 1-mL cultures of strains grown overnight in LSW-70 broth using the Qiagen DNeasy tissue extraction kit and following the manufacturers protocol for gram-negative bacteria.

\section{Phylogenetic analysis}

For a broad-scale analysis of fishes that bear light organs, sequences of two mitochondrial genes, the $16 \mathrm{~S}$ ribosomal RNA (16S) gene and the cytochrome oxidase subunit I (COI) gene, were used from 22 species. Sequences for the outgroup, Cyprinus carpio, were obtained from GenBank. For a fine-scale analysis, restricted to leiognathids, the $16 \mathrm{~S}$ and COI genes, together with sequences of the nuclear genes for histone H3 subunit (H3) and the 28S rRNA (28S) (Sparks et al., 2005), were used (see Appendix A for GenBank accession numbers). Because the $16 \mathrm{~S}$ and the $28 \mathrm{~S}$ genes vary in length, all fish sequence data were analyzed by direct optimization as implemented in OY (POY without parallel options) (Wheeler et al., 2003). In both analyses, each gene was placed in its own fragment so that only homologous sequences were compared. A total of 20 OY replicates for each fish phylogeny included randomizing outgroup and taxon order input (-randomizeoutgroup -nooneasis), retaining a maximum of two trees per initial build (-buildmaxtrees 2), all changes set to a cost of 1 (-change 1 -gap 1 -extensiongap 1), and two iterations of ratcheting with $30 \%$ data perturbation 
Table 1

Sources of bacterial strains used in this study

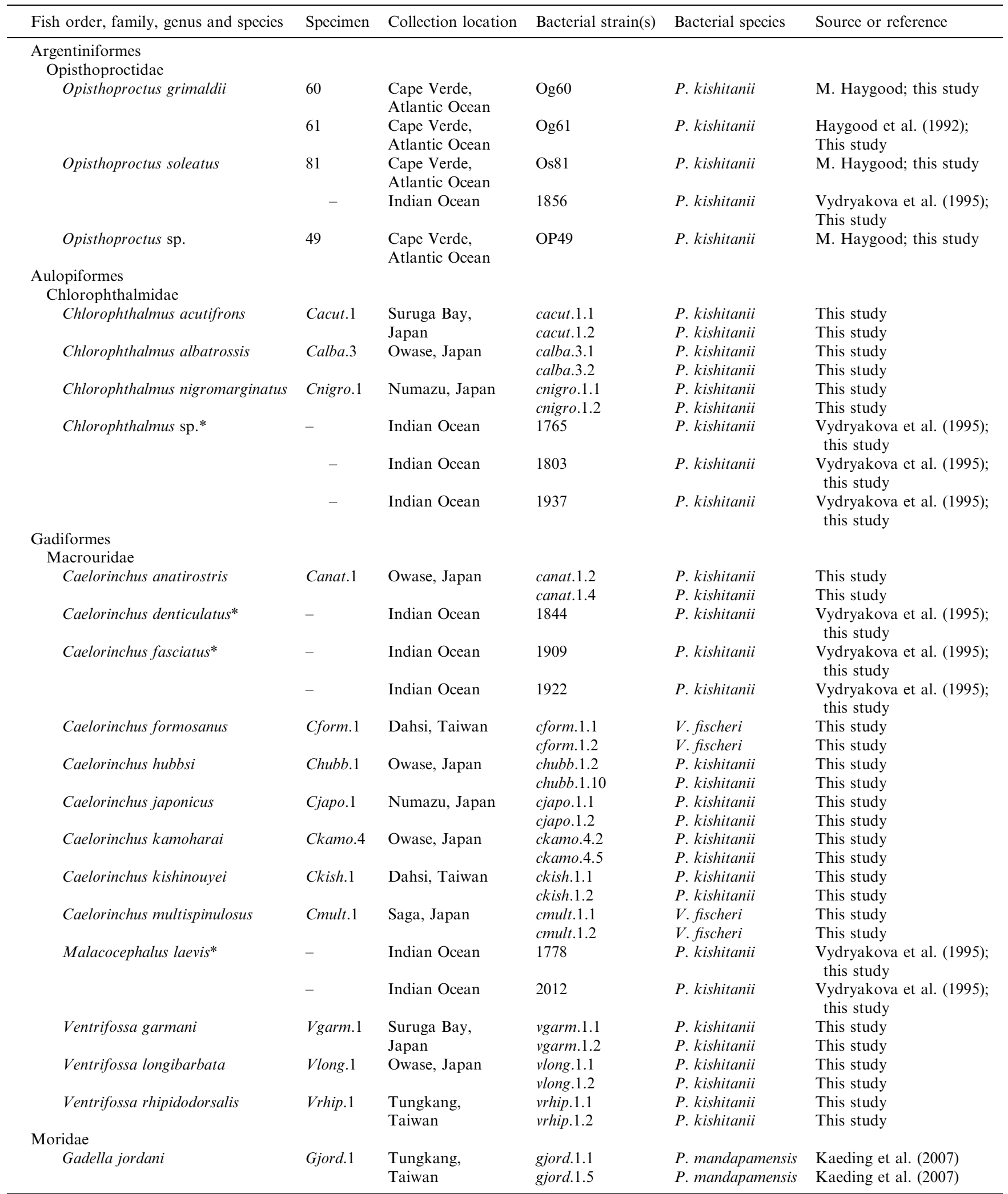


Table 1

Continued

\begin{tabular}{|c|c|c|c|c|c|}
\hline Fish order, family, genus and species & Specimen & Collection location & Bacterial strain(s) & Bacterial species & Source or reference \\
\hline \multirow[t]{2}{*}{ Physiculus japonicus } & Pjapo. 2 & Odawara, Japan & pjapo.2.1 & P. kishitanii & This study \\
\hline & & & pjapo. 2.2 & P. kishitanii & This study \\
\hline \multicolumn{6}{|l|}{ Beryciformes } \\
\hline \multicolumn{6}{|l|}{ Trachichthyidae } \\
\hline \multirow[t]{2}{*}{ Aulotrachichthys prosthemius } & Apros.3 & Odawara, Japan & apros. 3.2 & P. kishitanii & $\begin{array}{l}\text { Ast and Dunlap (2004); } \\
\text { Dunlap and Ast (2005) }\end{array}$ \\
\hline & & & apros. 3.3 & P. kishitanii & $\begin{array}{l}\text { Ast and Dunlap (2004); } \\
\text { Dunlap and Ast (2005) }\end{array}$ \\
\hline \multicolumn{6}{|l|}{ Monocentridae } \\
\hline \multirow[t]{2}{*}{ Monocentris japonicus } & Mjapo.7 & Wagu, Japan & mjapo.7.1 & V. fischeri & This study \\
\hline & & & mjapo.7.2 & V. fischeri & This study \\
\hline \multicolumn{6}{|l|}{ Perciformes } \\
\hline \multicolumn{6}{|l|}{ Acropomatidae } \\
\hline \multirow[t]{2}{*}{ Acropoma hanedai } & Ahane.1 & Tungkang, & ahane.1.1 & P. kishitanii & This study \\
\hline & & Taiwan & ahane.1.2 & P. kishitanii & This study \\
\hline \multirow[t]{2}{*}{ Acropoma japonicum } & Ajapo.2 & Dahsi, Taiwan & ajapo.2.1 & P. mandapamensis & Kaeding et al. (2007) \\
\hline & & & ajapo.2.16 & P. leiognathi & Kaeding et al. (2007) \\
\hline \multicolumn{6}{|l|}{ Leiognathidae } \\
\hline Gazza achlamys & Gachl.1 & $\begin{array}{l}\text { Iloilo, } \\
\text { Philippines }\end{array}$ & gachl.1.1 & P. leiognathi & Dunlap et al. (2004) \\
\hline \multirow[t]{2}{*}{ Gazza minuta } & Gminu.9 & Tigbauan, & gminu.9.1 & P. leiognathi & This study \\
\hline & & Philippines & gminu.9.2 & P. leiognathi & This study \\
\hline \multirow[t]{2}{*}{ Leiognathus equulus } & Lequu.16 & Taipei, Taiwan & lequи. 16.2 & P. leiognathi & This study \\
\hline & & & lequи. 16.3 & P. leiognathi & This study \\
\hline Leiognathus fasciatus & Lfasc. 7 & $\begin{array}{l}\text { Awase, } \\
\text { Okinawa }\end{array}$ & lfasc. 7.3 & P. leiognathi & This study \\
\hline "Leiognathus" jonesi & Ljone.1 & $\begin{array}{l}\text { Iloilo, } \\
\text { Philippines }\end{array}$ & ljone.1.1 & P. leiognathi & Dunlap et al. (2004) \\
\hline \multirow{2}{*}{$\begin{array}{l}\text { "Leiognathus" nuchalis } \\
\text { "Leiognathus" philippinus }\end{array}$} & Lnuch. 2 & Odawara, Japan & lnuch.2.1 & P. leiognathi & This study \\
\hline & Lphil.1 & $\begin{array}{l}\text { Iloilo, } \\
\text { Philippines }\end{array}$ & lphil.1.1 & P. leiognathi & Dunlap et al. (2004) \\
\hline "Leiognathus" splendens & - & Gulf of Siam & ATCC $25521^{\mathrm{T}}$ & P. leiognathi & $\begin{array}{l}\text { Boisvert et al. (1967); } \\
\text { Dunlap et al. (2004) }\end{array}$ \\
\hline Photoplagios elongatus & Lelon. 2 & $\begin{array}{l}\text { Manazuru, } \\
\text { Japan }\end{array}$ & lelon.2.1 & P. leiognathi & This study \\
\hline Photoplagios leuciscus & Lleuc. 1 & $\begin{array}{l}\text { Palawan, } \\
\text { Philippines }\end{array}$ & lleuc.1.1 & P. leiognathi & $\begin{array}{l}\text { Dunlap et al. (2004); } \\
\text { Dunlap and Ast (2005) }\end{array}$ \\
\hline Photoplagios rivulatus & Lrivu. 17 & Odawara, Japan & lrivu.17.1 & P. leiognathi & This study \\
\hline Photoplagios stercorarius & Lster. 2 & $\begin{array}{l}\text { Tigbauan, } \\
\text { Philippines }\end{array}$ & lster.2.1 & P. leiognathi & This study \\
\hline Photopectoralis bindus & Lbind.1 & $\begin{array}{l}\text { Palawan, } \\
\text { Philippines }\end{array}$ & lbind.1.1 & P. leiognathi & Dunlap et al. (2004) \\
\hline \multirow[t]{2}{*}{ Photopectoralis panayensis } & Ppana.3 & Tigbauan, & ppana.3.2 & P. leiognathi & Kaeding et al. (2007) \\
\hline & & Philippines & ppana.3.3 & P. mandapamensis & Kaeding et al. (2007) \\
\hline Secutor cf. insidiator & Sinsi.1 & $\begin{array}{l}\text { Palawan, } \\
\text { Philippines }\end{array}$ & sinsi. 1.2 & P. leiognathi & Dunlap et al. (2004) \\
\hline \multirow[t]{2}{*}{ Secutor megalolepis } & Smega.4 & Tigbauan, & smega.4.1 & P. leiognathi & This study \\
\hline & & Philippines & smega.4.2 & P. leiognathi & This study \\
\hline
\end{tabular}

*Genomic DNA only.

saving one tree per iteration (-ratchettbr 2 -rachettrees 1 -ratchetpercent 30). Suboptimal trees were evaluated during each iteration and in the final refinement using slop commands (-slop 5 -checkslop 10). For both analyses, the fish data were also aligned by eye (rRNA genes) or inferred amino acid sequences (protein coding genes) and analyzed with parsimony using 1000 heuristic replicates with TBR in TNT (Goloboff et al., 2005); in these cases, gaps were treated as missing, and putative loop regions in the rRNA genes were excluded from the analysis. To put fishes bearing bacterial light organs in a phylogenetic context, a matrix of the COI gene was constructed that added non-luminous fishes and analyzed the data with static alignment in TNT. All jackknife values were calculated in TNT using either the implied alignment output from OY, or the handaligned data sets, with 10000 replicates and a 34\% independent probability of deletion. 
Phylogenies of the symbionts were reconstructed using the genes for DNA gyrase subunit B ( $g y r B)$, recombinase subunit $\mathrm{A}(\operatorname{rec} A)$, and luciferase $\alpha$-subunit $(\operatorname{lu} x A)$ in the broad-scale analysis set; because length differences among strains for each of these genes are minimal or non-existent, parsimony analysis of static alignments was used instead of direct optimization, and gaps were treated as informative. Sequences for the outgroup, Vibrio harveyi ATCC $14126^{\mathrm{T}}$, were obtained in this laboratory. For the second analysis, restricted to the symbionts of leiognathid fishes, gyr $B$ and $\operatorname{lu} x A$, together with the genes for luciferase subunit B (luxB), non-fluorescent flavoprotein $(l u x F)$, and a small portion of the gene for acyl-protein synthetase (luxE) were used for analysis of the leiognathid symbionts. Bacterial genes were aligned by inferred amino acid residue sequence and analyzed using a branch-and-bound search implemented in PAUP* portable version (Swofford, 2002), and jackknife percentages were calculated using 10000 replicates in TNT (see above). To test whether hypotheses consistent with codivergence of host and symbiont were only slightly less parsimonious, the extra steps needed to constrain symbiont trees to match host trees were calculated by directly manipulating symbiont trees in MacClade (Maddison and Maddison, 2005).

For primers and polymerase chain reaction amplification profiles for fish and bacterial genes, see Ast and Dunlap $(2004,2005)$ and Sparks et al. (2005). Polymerase chain reaction products were sequenced by staff of the University of Michigan Sequencing Core using the respective amplification primers and dye terminator cycle sequencing on a Perkin-Elmer ABI 3730 DNA Analyzer (Perkin-Elmer Corp., Waltham, MA).

\section{Cophylogeny analysis and re-analysis of Vibrio fischeri sequence data}

To test for host-symbiont codivergence in associations between sepiolid squids and Vibrio fischeri (Nishiguchi et al., 1998), we used the reconciled trees method, as implemented by cophylogeny mapping in TreeMap (Charleston and Page, 2002). This method assumes that host and associate trees will be congruent, because the two organisms share a common history. Where the two trees are not congruent, the method hypothesizes evolutionary events (i.e., associate duplication independent of host cladogenesis, associate loss from a host lineage, and associate switching from one host to another) necessary to make the associate tree congruent with that of the host. Because there are no objective criteria for weighting one kind of event more or less heavily than any other, settings for creating cophylogenies ("jungles", Charleston, 1998) included all noncodivergent (duplication, loss and host switch) event costs set to 1 ; these settings also have the advantage of making the total cost equivalent to a tally of noncodivergent events. The significance of each jungle was tested by comparing the jungle with 1000 randomized associate trees, where the null hypothesis is that the codivergences in the jungle are no more than would be observed between the host tree and a random associate tree. The $P$-value of a jungle is the percentage of times that random trees were recovered within the number of codivergences observed in that particular jungle. A high $P$-value indicates that random trees often recovered an equal or greater number of codivergences and therefore that the observed jungle is less significant; a low $P$-value indicates that random trees rarely recovered as many codivergences and therefore the observed jungle is more significant.

We also reanalyzed sequence data for $V$. fischeri strains (Nishiguchi et al., 1998), using the most recently updated versions of these data (AF034845-AF034851; Nishiguchi et al., 1998) downloaded from GenBank. This re-analysis identified a discrepancy in the genes used by Nishiguchi et al. (1998) in reconstructing the original symbiont tree. Sequence of the putative "gapA" gene for the outgroup Photobacterium leiognathi strain LN101 (AF034849; Nishiguchi et al., 1998) was difficult to align to the sequences of the six reported $V$. fischeri strains. BLAST analysis of the gapA gene sequence of $P$. leiognathi strain LN101 showed homology with gapA sequences of various species of Vibrio. The "gapA" sequences from the $V$. fischeri strains, however, matched most closely to the erythrose-4-phosphate dehydrogenase gene (epd) of other Vibrio species. Therefore, it appears that the sequence of the "gapA" genes reported for $V$. fischeri (Nishiguchi et al., 1998; Nishiguchi and Nair, 2003) are actually sequences of the epd gene, while the gap A sequence reported for Photobacterium leiognathi strain LN101 (Nishiguchi et al., 1998; Nishiguchi and Nair, 2003) is gapA. The two genes (epd and gapA) have some amino acid and functional identities and are thought to be the products of an ancient duplication event (e.g., Boschi-Muller et al., 1997; Bardey et al., 2005). It is possible that gapA primers used in the earlier study (Nishiguchi et al., 1998) misprimed the epd gene. Regardless, the reported outgroup sequence (gap A) was paralogous to the ingroup sequences (epd). Therefore, to test whether codivergence might be evident with use of the proper outgroup gene, we reanalyzed the original sequence data and used the epd gene sequence of $V$.loge $i$ (AY292956; Nishiguchi and Nair, 2003), a close relative of $V$. fischeri, as outgroup. Sequences of the epd genes of the seven bacterial strains were aligned by inferred amino acid sequence and analyzed with an exhaustive search in PAUP*. Jackknife resampling values were calculated using 1000 branch-and-bound searches. The resulting symbiont tree was compared using TreeMap with host trees presented in Nishiguchi et al. (1998, 2004). 


\section{Results}

\section{Sampling bioluminescent symbioses}

Specimens of 35 species of bacterially luminous fishes were collected at various locations in Japan, Okinawa, Taiwan, and the Philippine Islands (Fig. 1; Table 1), and strains of symbiotic bacteria from the light organs of these fishes were isolated (Materials and methods). Several of these fishes previously had not been analyzed phylogenetically, and for many of them the identities of their light-organ symbiotic bacteria previously had not been reported. This extensive collection effort provided material for a taxonomically broad-scale phylogenetic analysis, involving 22 host species in seven families of four teleost orders (Nakabo, 2002; Nelson, 2006), and for a fine-scale analysis focused on a single family, Leiognathidae, for which 16 species were examined. Furthermore, bacterial strains isolated from light organs of several additional fishes, or genomic DNA of those strains, for which the fish specimen was not available, were identified phylogenetically and included in this study to test more fully the fish family bacterial species specificity (Tables 1 and 2).

\section{Broad-scale analysis}

Direct optimization analysis of the taxonomically broad sampling of fishes, based on sequences of the $16 \mathrm{~S}$ rRNA and COI genes, resulted in a single shortest hypothesis of relationships (Fig. 2). The relationships resolved for the fishes were generally consistent with both morphology-based taxonomy (Nelson, 2006) and recent molecular analyses (Miya et al., 2001, 2003). The only discrepancy is an inconsistency in the placement of acropomatids (Perciformes) as sister to beryciforms; difficulties resolving relationships between perciforms and beryciforms have been encountered previously (e.g., Miya et al., 2001). We note at a technical level that the implied alignment of sequence data from direct optimization analysis of the fishes (Fig. 2) hypothesized that several insertion-deletion events had occurred in the examined genes. Specifically, where the original lengths of mitochondrial 16S rRNA gene fragments ranged from 569 bp (Gadella jordani) to 586 bp (Chlorophthalmus albatrossis), the implied alignment resulting from direct optimization was $659 \mathrm{bp}$. In this analysis, the mitochondrial COI fragments were $658 \mathrm{bp}$, and direct optimization introduced a single gap into the alignment, for an implied alignment length of $659 \mathrm{bp}$.

To compare the results obtained with direct optimization, we analyzed the data also with static alignment and parsimony methods (Appendix B). While the two resulting equally parsimonious hypotheses of relationships obtained in this approach differed in some ways from that obtained with direct optimization, the major clades resolved and the majority of the relationships were the same regardless of the method of analysis (Appendix B).

Tests of specificity and codivergence were made as rigorous as possible by analyzing bacterial strains isolated from the light organs of the individual specimens used to reconstruct the fish phylogeny (Materials and methods). Parsimony analysis of luminous bacteria, based on two strains per fish specimen and sequences of the $\operatorname{rec} A, \operatorname{gyr} B$ and $l u x A$ genes, provided phylogenetic criteria for species identifications, and it resulted in well-supported hypotheses (Fig. 2). Each resolved clade corresponded to a previously named taxon, Photobacterium kishitanii, Photobacterium leiognathi, Photobacterium mandapamensis and Vibrio fischeri, based on reference to type strains (Ast and Dunlap, 2004, 2005; Dunlap and Ast, 2005). No new bacterial lineages were identified. Single-gene phylogenies were mutually congruent.

Newly reported here are the identities of the symbiotic bacteria of several fishes (Table 1): Vibrio fischeri as the light-organ symbiont of Caelorinchus formosanus and Caelorinchus multispinulosis (Macrouridae); and Photobacterium kishitanii as the symbiont of Opisthoproctus grimaldii and Opisthoproctus soleatus (Opisthoproctidae), Chlorophthalmus acutifrons and Chlorophthalmus nigromarginatus (Chlorophthalmidae), and Caelorinchus denticulatus, Caelorinchus fasciatus, Caelorinchus japonicus, Caelorinchus kishinouyei, Malacocephalus laevis, Ventrifossa garmani and Ventrifossa rhipidodorsalis (Macrouridae). These identifications substantially increase the number of species of bacterially bioluminescent fishes whose light-organ bacteria have been identified using molecular phylogenetic criteria (Dunlap and Kita-Tsukamoto, 2006; Kaeding et al., 2007; Table 2).

These identifications in themselves provide a direct test of the hypothesis of host-symbiont specificity in bioluminescent symbioses (Reichelt et al., 1977; Ruby and Morin, 1978; Hastings and Nealson, 1981; Dunlap and Kita-Tsukamoto, 2006). Certain bacterial affiliations with these fishes appear consistent at a fish family level, e.g., $P$. kishitanii as symbiont of the three examined species of chlorophthalmids. Other affiliations contradict a strict family-level bacterial species specificity (Figs 2 and 3; Tables 1 and 2). Examples include $V$. fischeri and P. kishitanii as symbionts of different species of macrourids, and $P$. mandapamensis and $P$. kishitanii as symbionts of different species of morids. Furthermore, light organs of some specimens of the acropomatid $A$. japonicum (and the leiognathid $P$. panayensis, see below), harbor two different species of bacteria, a situation we call bacterial "cosymbiosis" (Kaeding et al., 2007) and that was noted previously for some sepiolid squids (Fidopiastis et al., 1998; Nishiguchi, 2000). Therefore, our analysis of a wide diversity of fishes from nature, including multiple specimens for 
Table 2

Host species of light-organ symbiotic luminous bacteria

\begin{tabular}{|c|c|c|c|c|c|c|}
\hline & \multicolumn{6}{|c|}{ Luminous bacteria* } \\
\hline \multicolumn{7}{|l|}{ Host species } \\
\hline \multicolumn{7}{|l|}{ Loliginidae } \\
\hline Uroteuthis (Photololigo) edulis $\ddagger$ & & & + & & & \\
\hline \multicolumn{7}{|l|}{ Sepiolida } \\
\hline Euprymna scolopes & & & & + & & \\
\hline Euprymna tasmanica & & & & + & & \\
\hline Sepiola affinis & & & & + & + & \\
\hline Sepiola intermedia & & & & + & + & \\
\hline Sepiola ligulata & & & & + & + & \\
\hline Sepiola robusta & & & & + & + & \\
\hline \multicolumn{7}{|l|}{ Aulopiformes } \\
\hline \multicolumn{7}{|l|}{ Chlorophthalmidae } \\
\hline Chlorophthalmus acutifrons & + & & & & & \\
\hline Chlorophthalmus albatrossis & + & & & & & \\
\hline Chlorophthalmus nigromarginatus & + & & & & & \\
\hline Chlorophthalmus sp. & + & & & & & \\
\hline \multicolumn{7}{|l|}{ Gadiformes } \\
\hline \multicolumn{7}{|l|}{ Macrouridae } \\
\hline Caelorinchus anatirostris & + & & & & & \\
\hline Caelorinchus denticulatus & + & & & & & \\
\hline Caelorinchus fasciatus & + & & & & & \\
\hline Caelorinchus formosanus & & & & + & & \\
\hline Caelorinchus hubbsi & + & & & & & \\
\hline Ventrifossa garmani & + & & & & & \\
\hline Ventrifossa longibarbata & + & & & & & \\
\hline Ventrifossa rhipidodorsalis & + & & & & & \\
\hline \multicolumn{7}{|l|}{ Moridae } \\
\hline Gadella jordani & & + & & & & \\
\hline Physiculus japonicus & + & & & + & & \\
\hline \multicolumn{7}{|l|}{ Lophiiformes } \\
\hline \multicolumn{7}{|l|}{ Melanocetidae } \\
\hline Melanocetus johnsoni & & & & & & + \\
\hline Ceratiidae & & & & & & \\
\hline Cryptosaras couesii & & & & & & + \\
\hline Beryciformes & & & & & & \\
\hline Anomalopidae & & & & & & \\
\hline Anomalops alfredi & & & & & & + \\
\hline Anomalops katoptron & & & & & & + \\
\hline Photoblepharon palpebratus & & & & & & + \\
\hline Photoblepharon steinetzi & & & & & & + \\
\hline Trachichthyidae & & & & & & \\
\hline Aulotrachichthys prosthemius & + & & & & & \\
\hline Monocentridae & & & & & & \\
\hline Cleidopus gloriamaris & & & & + & & \\
\hline
\end{tabular}




\begin{tabular}{|c|c|c|c|c|c|c|}
\hline & \multicolumn{6}{|c|}{ Luminous bacteria* } \\
\hline & P. kishitanii & P. mandapamensis $\dagger$ & P. leiognathi & $V$. fischeri & $V . \log e i$ & Not named \\
\hline Monocentris japonicus & & & & + & & \\
\hline \multicolumn{7}{|l|}{ Perciformes } \\
\hline \multicolumn{7}{|l|}{ Acropomatidae } \\
\hline Acropoma hanedai & + & & & & & \\
\hline Acropoma japonicum & & + & + & & & \\
\hline \multicolumn{7}{|l|}{ Apogonidae } \\
\hline Siphamia versicolor & & + & & & & \\
\hline \multicolumn{7}{|l|}{ Leiognathidae } \\
\hline Gazza achlamys & & & + & & & \\
\hline Gazza minuta & & & + & & & \\
\hline Leiognathus equulus & & & + & & & \\
\hline Leiognathus fasciatus & & & + & & & \\
\hline "Leiognathus" jonesi & & & + & & & \\
\hline "Leiognathus" nuchalis & & & + & & & \\
\hline “Leiognathus" philippinus & & & + & & & \\
\hline "Leiognathus" splendens & & & + & & & \\
\hline Photopectoralis bindus & & + & + & & & \\
\hline Photopectoralis panayensis & & + & + & & & \\
\hline Photoplagios elongatus & & & + & & & \\
\hline Photoplagios leuciscus & & & + & & & \\
\hline Photoplagios rivulatus & & & + & & & \\
\hline Photoplagios stercorarius & & & + & & & \\
\hline Secutor cf. insidiator & & & + & & & \\
\hline Secutor megalolepis & & & + & & & \\
\hline
\end{tabular}

*Identifications of light-organ symbiotic bacteria based on DNA sequence-based phylogenetic criteria. Data are from Ast and Dunlap (2005), Dunlap et al. (2004), Fidopiastis et al. (1998), Haygood and Distel (1993), Haygood et al. (1992), Kaeding et al. (2007), Nishiguchi (2000), Wolfe and Haygood (1991), Wada et al. (2006), this study, and previously unpublished data of this laboratory. Not listed are the many host species from which light-organ bacteria have been identified only by phenotypic traits (e.g., Reichelt et al., 1977; Ruby and Morin, 1978; see also Herring and Morin, 1978).

$\dagger$ Photobacterium mandapamensis is referred to in some publications as Photobacterium leiognathi ssp. mandapamensis (Ast and Dunlap, 2004; Wada et al., 2006).

†Identified as Doryteuthis kensaki (Fukasawa and Dunlap, 1986).

most taxa, does not support strict host family bacterial species specificity in bioluminescent symbiosis.

With respect to the hypothesis of host-symbiont codivergence, the lack of strict species specificity suggests that codivergence would not be evident. This view is affirmed by a visual comparison of the fish and bacterial phylogenies, which reveals no obvious topological congruence for the fish and bacterial phylogenies for the majority of associations. In general, the bacterial phylogeny is much less structured than that of the fish, with fewer clades resolved overall. The limited divergence of the bacteria is most distinct for P. kishitanii, which shows only slight divergence among strains that are symbiotic with a phylogenetically diverse group of fishes, e.g., Acropomatidae, Trachichthyidae, Chlorophthalmidae, Moridae and Macrouridae. This point is emphasized by the observation that bacteria indistinguishable phylogenetically or nearly so from each other, for example, ahane.1.1, apros.3.2, cacut.1.1 and calba.3.2, are symbiotic with distantly related fishes. Furthermore, in those cases in which the bacteria show phylogenetic structure, that structure is distinct from the structure of host relationships (Fig. 2). A lack of congruence is also evident from visual comparison of the bacterial phylogeny with hypotheses for fishes resulting from static alignment and parsimony methods (Appendix B). These results indicate that evolutionary divergence of the bacteria has not tracked that of the host fishes whose light organs the bacteria colonize.

To test the possibility that there is a slightly less parsimonious solution in which the symbiont phylogeny matches the host phylogeny, we manually manipulated the symbiont phylogeny (Materials and methods), constraining it to match the host phylogeny. This change, however, caused the phylogeny to double in length, and it substantially reduced the character statistics (for data, see legend for Fig. 2). These results indicate there is not a "near-most" parsimonious solution in which the symbiont phylogeny matches the host phylogeny. We also attempted to test for codivergence using reconciled trees analysis (Page, 1994), as implemented in the program TreeMap (Charleston and Page, 2002). These efforts were not successful, however; the program, which assumes codivergence and identifies exceptions to it, was 


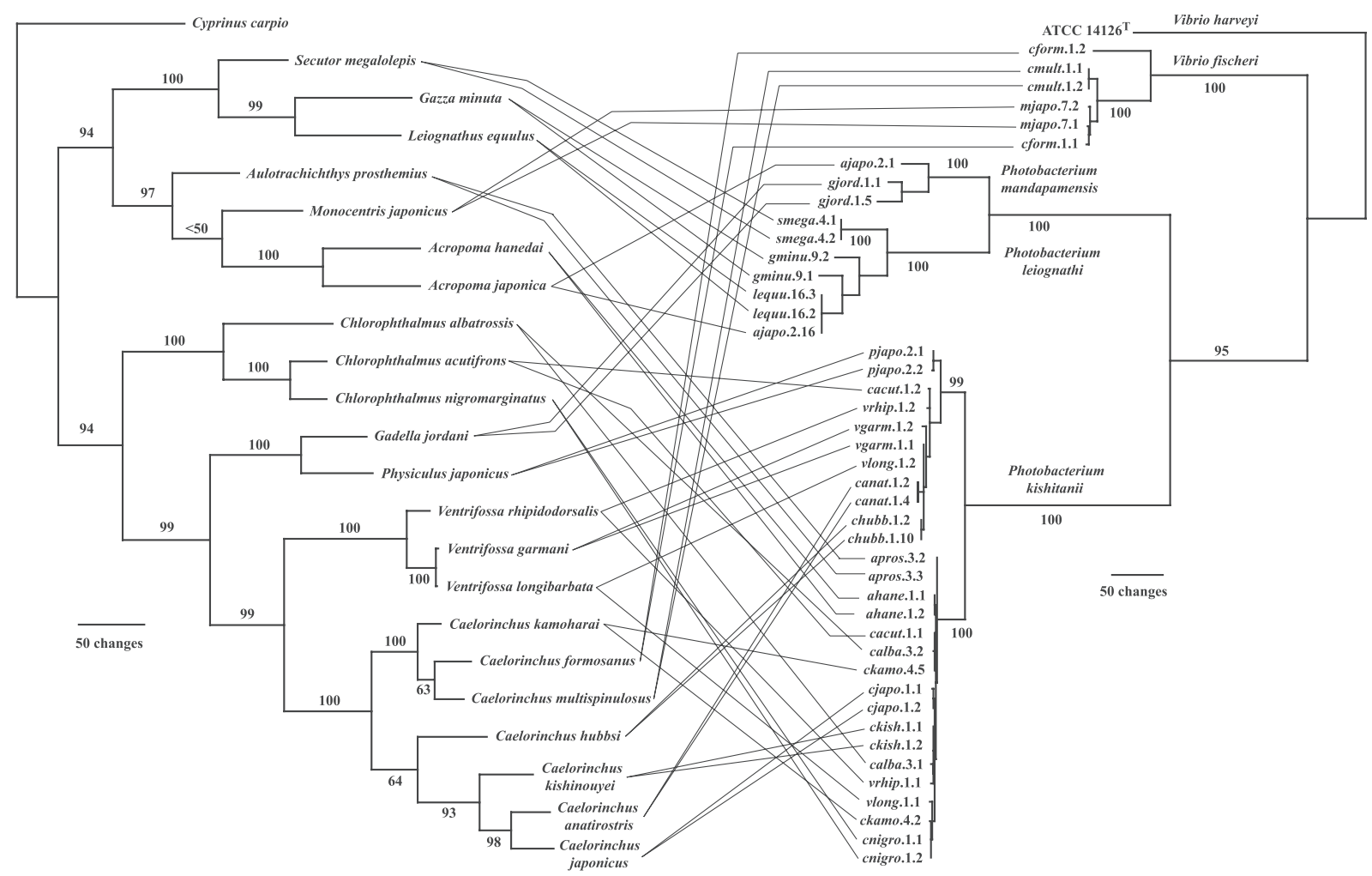

Fig. 2. Phylogenies of bacterially bioluminescent fishes and their symbiotic bacteria. Fish specimens represent 22 species in seven families from four teleost orders. The bacteria analyzed were taken from the light organs of the same specimen used for phylogenetic analysis. Genes analyzed were mitochondrial 16S rRNA and COI genes for the fish, and $g y r B$, recA and $l u x A$ for the bacteria. The fish data were analyzed with OY (see Materials and methods for settings), which resulted in a single most parsimonious hypothesis $(1318$ aligned nucleotides, length $=2074, \mathrm{CI}=0.44, \mathrm{RI}=0.62)$. The data for bacteria (2742 nucleotides, 871 parsimony informative) were analyzed with a branch and bound search in PAUP, and the tree shown is 1 of 2664 equally most parsimonious trees (length $=1757, \mathrm{CI}=0.71, \mathrm{RI}=0.94$ ). A consensus of all most parsimonious hypotheses demonstrates that the trees differ only in minor rearrangements of taxa at the tips of branches (not shown). Numbers at major nodes are jackknife support values (see Materials and methods). When the symbiont hypothesis was constrained to match the host hypothesis, the length and fit measures worsened (length $=3996, \mathrm{CI}=0.31, \mathrm{RI}=0.68$ ).

not able to handle the large number of taxa and the absence of the general congruence of these data (see Discussion for comments on this issue). In summary, the results of this broad-scale analysis demonstrate that most of the phylogenetic relationships among the bacteria do not reflect the phylogenetic relationships among the fishes.

An apparent host-symbiont specificity is seen, however, for the three leiognathid fishes included in this analysis, Gazza minuta, Leiognathus equulus and Secutor megalolepis, and their strains of P. leiognathi (Fig. 2). Furthermore, the patterns of host and symbiont divergence for these three associations approximate each other, although the extent of divergence is much greater for the fish than for the bacteria. This apparent congruence suggests that leiognathid fishes and their strains of $P$. leiognathi might have codiverged. Alternatively, the small sample size, three host taxa, could result in congruence simply by chance. To distinguish between these possibilities and determine if leiognathids and their bacteria present a special case of host-symbiont specificity and codivergence among bacterially bioluminescent fishes, we examined several additional species of leiognathids.

Fine-scale analysis: leiognathid fishes and Photobacterium leiognathi

For fine-scale analysis of Leiognathidae, 16 species of leiognathid fishes and their symbiotic light-organ bacteria were tested. For the fish, sequences of two additional genes, the histone $\mathrm{H} 3$ and 28S rRNA genes, were available for many species from our earlier work on phylogeny of Leiognathidae (Sparks et al., 2005), and the sequences of these genes were included in the analysis with the mitochondrial $16 \mathrm{~S}$ and COI gene sequences. For the bacteria, obtaining strains from the light organs of the specific fish specimens used for phylogenetic analysis was not possible in all cases; however, strains isolated from other specimens of those species, generally collected at the same time and place, were used. Together with $g y r B$ and $\operatorname{lu} x A$, sequences of 


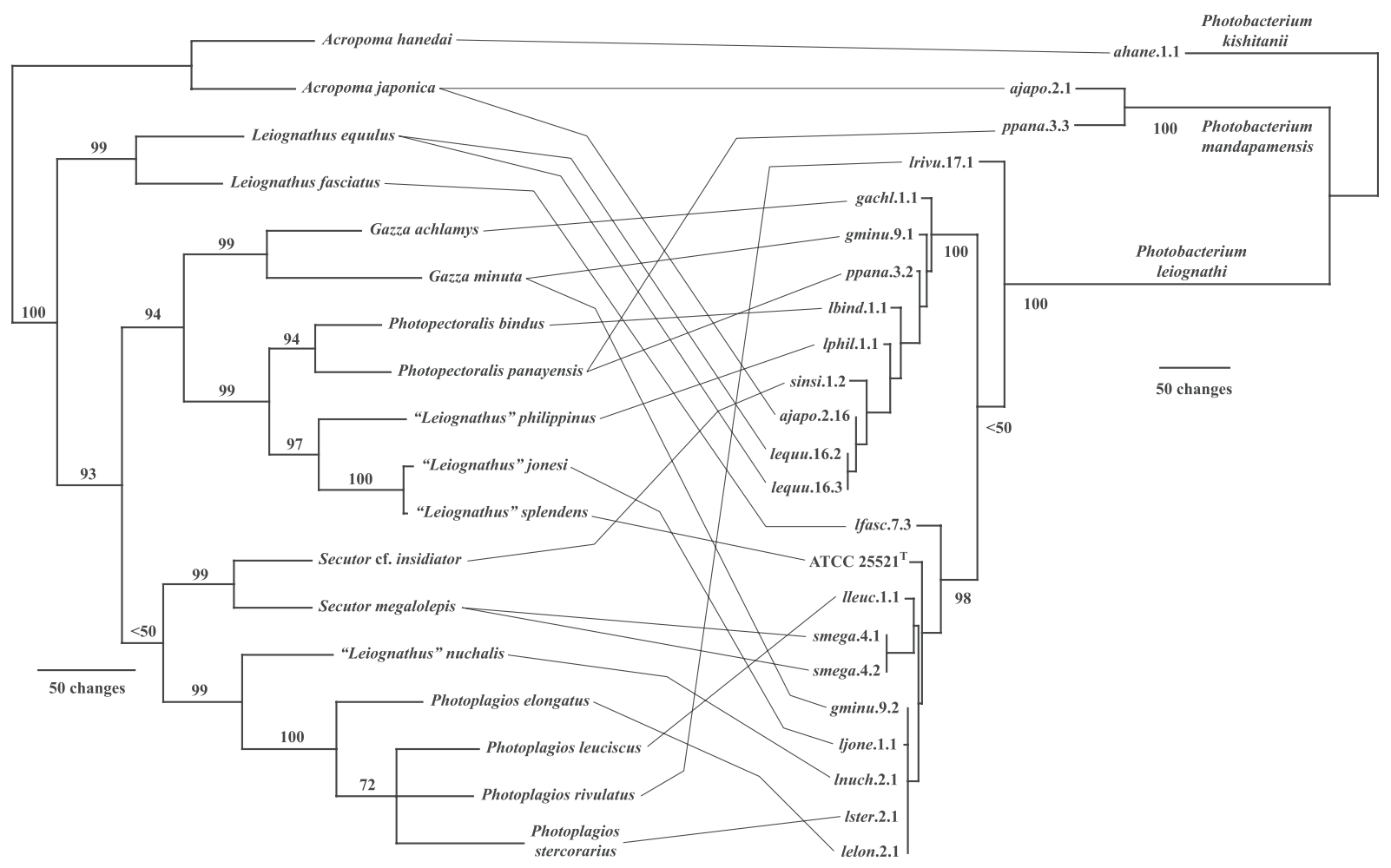

Fig. 3. Phylogenies of leiognathid fishes and their symbiotic luminous bacteria. Genes analyzed for fish were mitochondrial $16 \mathrm{~S}$ rRNA and COI genes, and the nuclear histone $\mathrm{H} 3$ and $28 \mathrm{~S}$ rRNA genes. Genes analyzed for bacteria were gyr $B, \operatorname{lux} A$, luxB, luxF (not present in $P$. leiognathi), and a small part of luxE. The fish data were analyzed with OY (see Materials and methods for settings), which resulted in a single most parsimonious hypothesis (2229 aligned nucleotides, length $=1434, \mathrm{CI}=0.51, \mathrm{RI}=0.478$ ). The data for bacteria (3965 aligned nucleotides total, 592 parsimony informative) were analyzed with a branch and bound search in PAUP, resulting in three equally most parsimonious hypotheses (length $=1004$, $\mathrm{CI}=0.76, \mathrm{RI}=0.85$ ), one of which is shown here (a strict consensus of the three shows minor rearrangements at some tips and does not change overall topology). Numbers at major nodes are jackknife support values (see Materials and methods). When the symbiont hypothesis was constrained to match the host hypothesis, the length and fit measures worsened (length $=2055, \mathrm{CI}=0.32, \mathrm{RI}=0.21$ ), and were similarly worsened when the node on the host tree with $<50 \%$ jackknife support was collapsed (length $=2053, \mathrm{CI}=0.32, \mathrm{RI}=0.22$ ).

three additional loci, $\operatorname{lu} x B, \operatorname{lu} x F$, and a portion of $\operatorname{lux} E$, were used; the sequences of these genes have diverged in Photobacterium (Ast and Dunlap, 2004, 2005; Dunlap et al., 2004; Dunlap and Ast, 2005) and therefore provide a strong test of phylogeny.

Direct optimization of the four fish genes (16S, COI, $\mathrm{H} 3$ and $28 \mathrm{~S}$ genes) resulted in a single hypothesis of relationships among leiognathids (Fig. 3). The relationships resolved were in general agreement with our previous results (Sparks et al., 2005). Somewhat fewer taxa were used here, however, in that taxa chosen for this analysis were those for which bacterial symbionts are available. We also analyzed these data with static alignment and parsimony methods (Appendix B). Two equally parsimonious hypotheses of relationships were obtained, and each differed in some ways from that obtained with direct optimization. Nonetheless, the major clades resolved and the majority of the relationships were the same regardless of the method of analysis (Appendix B).

Parsimony analysis of the five bacterial genes $(\operatorname{gyr} B$, $\operatorname{lu} x A, \operatorname{lu} x B, \operatorname{lu} x F$ and $\operatorname{lu} x E$ ) resulted in three hypotheses of relationships among the symbionts of these fish species, which differed only in minor details (Fig. 3). Most species of leiognathids harbor P. leiognathi in their light organs (Fig. 3). A striking exception is the presence of $P$. mandapamensis, together with $P$. leiognathi, in light organs of Photopectoralis panayensis (and Photopectoralis bindus) (Kaeding et al., 2007), which demonstrates that $P$. leiognathi is not the exclusive light-organ symbiont of Leiognathidae. The co-symbiosis of $P$. leiognathi and P. mandapamensis provides additional evidence that strict fish family bacterial species specificity does not characterize bioluminescent symbioses.

With this larger taxon set, the apparent congruence seen for the three leiognathids and their bacteria (Fig. 2) was no longer evident (Fig. 3). The bacteria were less divergent than their host fishes, and while clade structure was present in $P$. leiognathi, it did not reflect the clade structure of the host fishes. For example, the symbiotic bacteria of the closely related fishes, Secutor megalolepis and Secutor insidiator, represent different clades, as do the two sampled symbionts of Gazza minuta. These results indicate that the apparent 
topological congruence of leiognathids and their bacteria seen in Fig. 2 results from a limited sample.

Visual comparison of the bacterial phylogeny (Fig. 3) with the phylogenies of leiognathid fishes resulting from static alignment (Appendix B) also reveals no congruence. Furthermore, as was found for the broad-scale analysis, when the leiognathid symbiont phylogeny was constrained to match that of the host, the phylogeny length more than doubled, and the character statistics decreased by more than half (for data, see legend for Fig. 3). These results indicate for this fine-scale analysis that there is not a "near-most" parsimonious solution in which the symbiont phylogeny matches the host phylogeny. As was done with the broad-scale analysis, TreeMap was used to test for codivergence, and as above, the tests were unsuccessful due to failure of the application.

\section{Analysis of sepiolid squid-Vibrio fischeri "parallel evolution"}

The absence of codivergence between fishes and their light-organ symbiotic bacteria described here differs from a report on bacterially luminous squids (Nishiguchi et al., 1998). In the squid study, congruence was reported for phylogenies of sepiolid squids and their symbiotic strains of $V$. fischeri and was interpreted as "parallel evolution" (Nishiguchi et al., 1998). To test the conclusions of the squid study, which is cited as evidence of cospeciation and coevolution in bioluminescent symbioses (Thompson, 2005; Jones et al., 2006), we analyzed results and data from the original study (Nishiguchi et al., 1998), as well as data on $V$. fischeri and on sepiolid squids from more recent studies (Nishiguchi and Nair, 2003; Nishiguchi et al., 2004).

Initially, we applied cophylogeny mapping with TreeMap (Page and Charleston, 1998; Charleston and Page, 2002) to the originally reported symbiont tree (Nishiguchi et al., 1998; Fig. 1; reproduced here as Fig. 4a), to test the hypothesis of "parallel evolution".
With the smaller number of taxa, TreeMap performed effectively (see Appendix $\mathrm{C}$ for a list of all jungles and their scores). TreeMap analysis indicated that the original symbiont and squid ITS trees (Fig. 4b) were entirely congruent, with no non-codivergent events required. In contrast, however, few codivergences were seen for the original symbiont tree and the squid COI tree (Nishiguchi et al., 1998; Fig. 4c) or for the squid combined genes tree (Nishiguchi et al., 2004; Fig. 4d). The claim of "parallel evolution" therefore holds only for one of the two squid trees from the original analysis (Nishiguchi et al., 1998; Fig. 1A). Otherwise, several non-codivergent events were required to reconcile the trees, and most jungles have low significance values (Appendix C).

A discrepancy exists, however, in the genes used by Nishiguchi et al. (1998) in reconstructing the original symbiont tree. The bacterial sequence referred to in that study as gapA (encoding glyceraldehyde-3-phosphate dehydrogenase) is actually two different genes, epd (encoding erythrose-4-phosphate dehydrogenase), sequenced for the sepiolid squid strains, and gapA, sequenced for the outgroup, a strain of $P$. leiognathi (Materials and methods). To correct this problem, we reanalyzed the original $V$. fischeri sequence data (Nishiguchi et al., 1998), but used the V. logei epd gene sequence as outgroup (Materials and methods). Re-analysis of sequences of the six reported strains of $V$. fischeri, three from species of Sepiola (SA1, SR5, SI6) and three from species of Euprymna (ES114, EM17, ET101) resulted in a cladogram with a different topology of relationships than reported in the original squid study (Nishiguchi et al., 1998). Specifically, strain SR5, a symbiont of Sepiola robusta, was resolved, with strong jackknife resampling support, as nested within a clade otherwise consisting of Euprymna symbionts (Fig. 4e). This result, which shows that bacteria from different host species do not necessarily represent different clades, contradicts strict host-symbiont codivergence and therefore is not consistent with "parallel evolution".

\footnotetext{
Fig. 4. Cophylogeny analysis of sepiolid squids and Vibrio fischeri. Shown are symbiont phylogenies and TreeMap jungles. All strains are $V$. fischeri except the outgroups Photobacterium leiognathi LN101 and Vibrio logei ATCC 15382. Strain names include information about the host species from which the strain was isolated; e.g., SA1 was isolated from Sepiola affins, etc. Squid names in jungles have been shortened for visual clarity; "S." stands for Sepiola, "E." stands for Euprymna. Symbiont phylogenies appear in lighter lines, and host phylogenies are in heavier lines. Black circles in the symbiont tree (near nodes on the host tree) represent codivergence events (Co), white circles or squares represent duplication events (Du), gray circles represent losses (Lo) from the lineage that the symbiont tree fails to track, and arrows indicate the direction of a host switch (Sw) (always coupled with a duplication in these jungles). See individual representative jungle figures for the numbers of each events. The jungles shown here have the fewest number of non-codivergent events. If jungles were tied for fewest events, the jungle shown is that with the best significance value. Note that the COI tree of Nishiguchi et al. (1998) is not presented as a consensus tree; therefore, the polytomy among Sepiola species was retained for cophylogeny testing. Numbers of events and significance values for all jungles are provided in Appendix C. (a) Symbiont phylogeny of Fig. 1 of Nishiguchi et al. (1998), including the reported bootstrap values at nodes. (b) Reported symbiont phylogeny of Nishiguchi et al. (1998) reconciled with host squid ITS phylogeny. (c) Reported symbiont phylogeny of Nishiguchi et al. (1998) reconciled with host squid COI phylogeny. (d) Reported symbiont phylogeny of Nishiguchi et al. (1998) reconciled with the host squid phylogeny of Nishiguchi et al. (2004). (e) Symbiont phylogeny reanalyzed using the epd gene of Vibrio logei as the outgroup (MPT = most parsimonious tree), with jackknife values at nodes. (f) Reanalyzed symbiont phylogeny reconciled with host squid ITS phylogeny of Nishiguchi et al. (1998). (g) Reanalyzed symbiont phylogeny reconciled with host squid COI phylogeny of Nishiguchi et al. (1998). (h) Reanalyzed symbiont phylogeny reconciled with host squid phylogeny of Nishiguchi et al. (2004).
} 
P. leiognathi gap $A, V$. fischeri strains epd

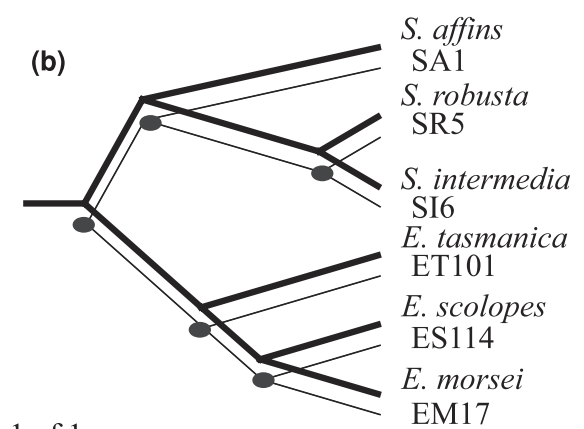

1 of 1

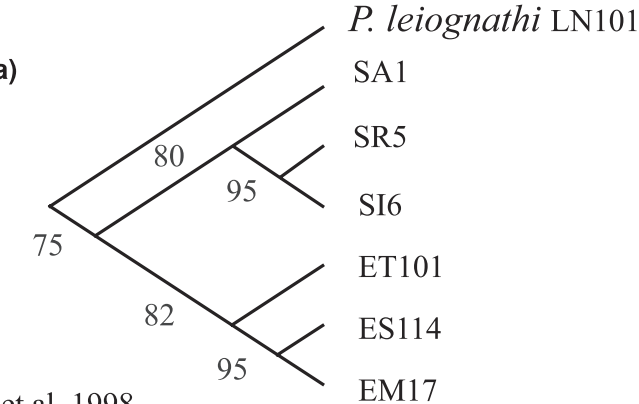

et al. 1998

$\mathrm{Co}=10, \mathrm{Sw}=0, \mathrm{Du}=0, \mathrm{Lo}=0 ;$ total $\operatorname{cost}=0$

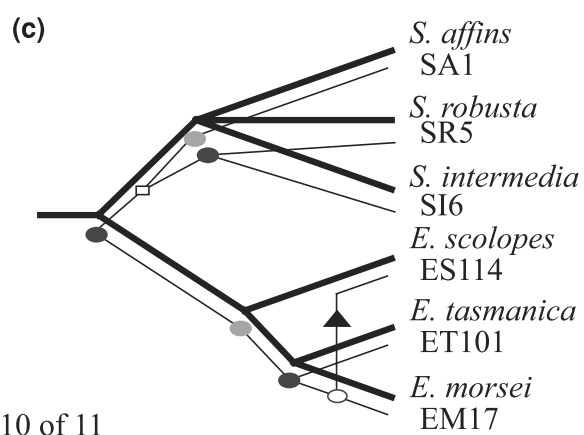

$\mathrm{Co}=6, \mathrm{Sw}=1, \mathrm{Du}=4, \mathrm{Lo}=2 ;$ total $\operatorname{cost}=7$

(d)
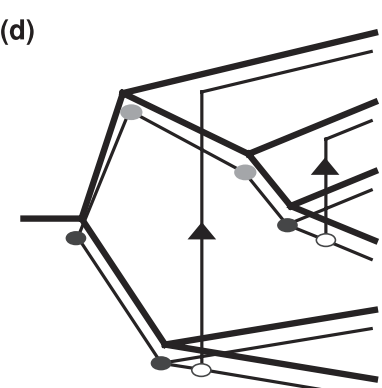

3 of 6

$\mathrm{Co}=6, \mathrm{Sw}=2, \mathrm{Du}=4, \mathrm{Lo}=2 ;$ total $\operatorname{cost}=8$ (e)

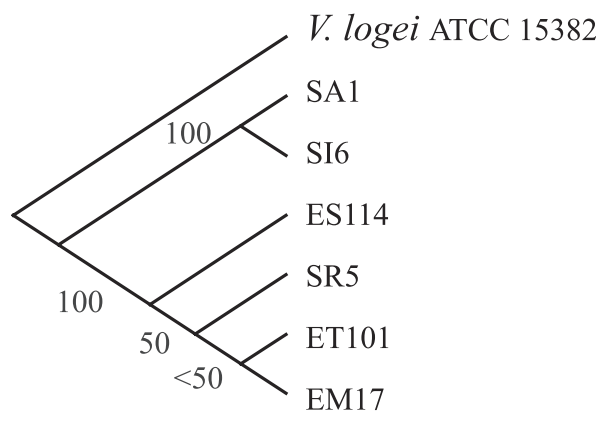

All strains epd, single MPT.

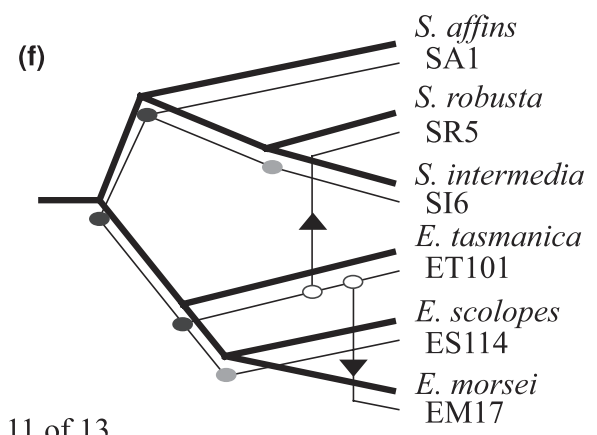

$\mathrm{Co}=6, \mathrm{Sw}=2, \mathrm{Du}=4, \mathrm{Lo}=2 ;$ total $\operatorname{cost}=8$
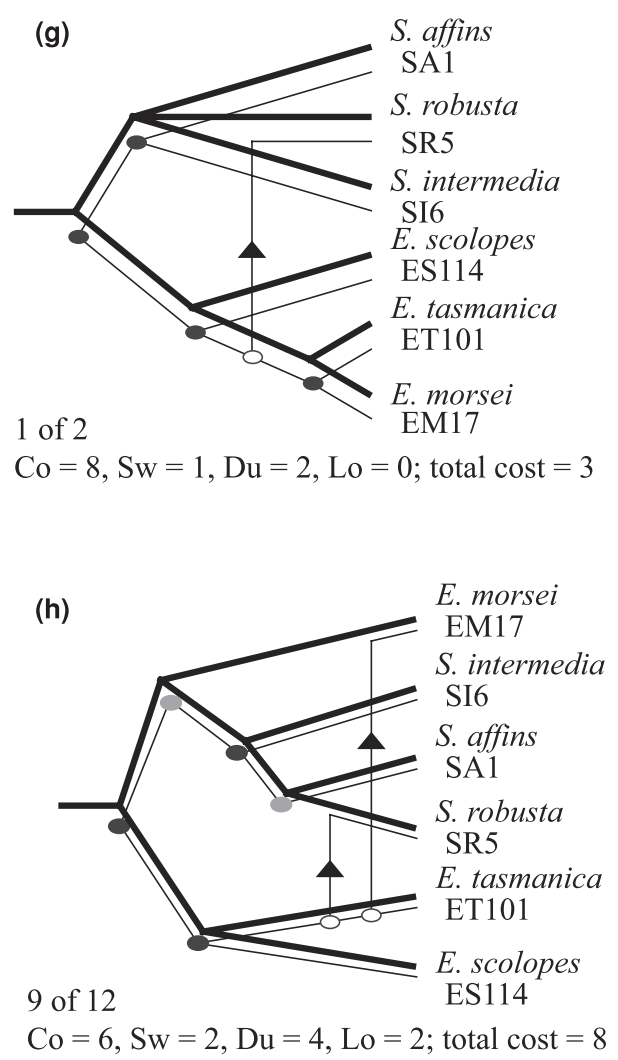
We next used cophylogeny analysis to compare squid host trees with this new symbiont tree. Strict codivergence between host squids and symbiotic $V$. fischeri strains was not observed for the squid ITS tree (Nishiguchi et al., 1998; Fig. 4f), the squid COI tree (Nishiguchi et al., 1998; Fig. 4g), or the most recent squid tree (Nishiguchi et al., 2004; Fig. 4h). In each case, several non-codivergent events, i.e., duplications, losses, or host switches, are needed to make the associate tree match the host tree. Furthermore, most jungles had low significance (i.e., relatively high $P$-values); that is, the observed host and associate trees did not have significantly more codivergences than did host and random associate trees. In the one case with a low $P$-value (i.e., more codivergences than expected at random) the squid COI tree and the symbiont tree (Fig. 4g), the hypothesis requires symbiont duplication and a host switch. These results, like those above, are not consistent with "parallel evolution".

We also considered an alternative criterion for testing cophylogeny, the absence of host switching (Appendix C). The initial squid study (Nishiguchi et al., 1998) presented empirical evidence from colonization assays that $V$. fischeri strains "native" to a given species of squid were competitively dominant in colonizing light organs of that squid species compared with strains of $V$. fischeri from other species of squid (Nishiguchi et al., 1998). Those results imply that host switching should not occur in the squid- $V$. fischeri symbiosis. In each TreeMap analysis, a single jungle was returned that did not require host switching, and that allowed us to evaluate cophylogeny in the absence of host switching. Examination of the jungles without host switches, however, revealed that each of them required a high number of other non-codivergent events to reconcile the host and symbiont trees (Appendix C).

Furthermore, a more recent phylogeny has been reported that includes additional symbiont strains of $V$. fischeri (Nishiguchi and Nair, 2003). In contrast to the initial study (Nishiguchi et al., 1998), this newer bacterial phylogeny shows a lack of host family symbiont specificity for squid-symbiotic strains of $V$. fischeri; i.e., there is no phylogenetic distinction between symbionts of Sepiola and symbionts of Euprymna, and several sepiolid squids ( $S$. affinis, $S$. intermedia, S. lingulata and $S$. robusta) were reported to have either $V$. fischeri or $V$. logei as light-organ symbionts. While the level of complexity of the reported symbiont phylogenetic hypothesis, especially given the polytomies, renders TreeMap analysis problematic, visual comparison of the symbiont phylogeny with squid trees readily reveals a lack of symbiont-host congruence.

In summary, analysis of results and data for sepiolid squids and $V$. fischeri refutes the claim of "parallel evolution" in the squid- $V$. fischeri bioluminescent symbioses (Nishiguchi et al., 1998). Evolutionary divergence of luminous bacteria symbiotic with squid, as shown above for luminous bacteria symbiotic with fishes (Figs 2 and 3), apparently is independent of evolutionary divergence of the host animals whose light organs these bacteria colonize.

\section{Discussion}

Obligate associations of endosymbiotic, intracellular bacteria with animals (e.g., Baumann et al., 1995; Hosokawa et al., 2006) provide paradigm examples of host-symbiont specificity and codivergence. The host animal's elaboration of tissues for culturing the bacteria, mechanisms for maternal transfer of the symbiont to the next generation of host, and genome reduction in the symbiont presumably reflect host-symbiont coevolutionary interactions. Here, we have examined the historical context of specificity and codivergence of bioluminescent mutualisms between luminous fishes and their light-organ symbiotic bacteria. We sought evidence that symbiotic associations between animals and extracellular, facultatively symbiotic, environmentally acquired bacteria also might exhibit a specificity and codivergence consistent with coevolutionary interactions. Bacterial symbionts from a taxonomically extensive sampling of bioluminescent associations were isolated and identified phylogenetically to test the hypothesis that these associations exhibit strict host family bacterial species specificity. The results of both a broad-scale analysis, using a wide diversity of fishes, and a fine-scale analysis focused on a single host family, Leiognathidae, contradicted a strict host-symbiont specificity and revealed no evidence for codivergence.

Robust clade structure was evident for the fish and the bacteria in the broad-scale analysis, but host and symbiont phylogenies did not exhibit topological congruence (Fig. 2). An apparent exception was the matchup of three leiognathid species and their strains of $P$. leiognathi, which was tested further with a fine-scale analysis of a larger number of leiognathid associations, 16 species. With the larger number of taxa, leiognathid and $P$. leiognathi phylogenies were no longer congruent; clade structure is evident in the bacteria, but again, even in this single host family analysis, it does not reflect clade structure of the fish (Fig. 3). Furthermore, analysis of results and data from sepiolid squid- $V$. fischeri associations revealed no convincing evidence of codivergence. Therefore, the evolutionary divergence of luminous bacteria apparently is independent of that of the host fishes and squids whose light organs they colonize. These results indicate that bioluminescent symbioses represent a class of symbiosis that is entirely different from obligate endosymbiotic associations. The lack of strict specificity and codivergence in bioluminescent symbioses, together with their general biological 
features of bacterial extracellularity and symbiont acquisition from the environment suggest that this class of symbiosis is not likely to involve host-symbiont coevolutionary interactions.

Visual inspection of the tanglegrams generated by linking hosts and their individual symbionts (Figs 2 and 3) provides strong evidence for the lack of specificity and codivergence between luminous bacteria and their fish hosts. Attempts to analyze codivergence between fish and their light-organ bacteria using the reconciled trees method of Page (1994), as implemented with TreeMap (Charleston and Page, 2002), were not successful; TreeMap was not able process the large number of taxa and lack of general congruence of our fish and bacteria data. A particular problem for mapping methods apparently is the computational complexity inherent to analysis of a single symbiont infecting multiple hosts, a problem that is exacerbated by the large number of taxa and the lack of general congruence between host and symbiont phylogenies (Jackson, 2004; Charleston and Perkins, 2006). TreeMap was effective, however, with the smaller number of taxa in the analysis of sepiolid squid and $V$. fischeri (Fig. 4; Appendix C).

The lack of congruence between the phylogenies of leiognathid fishes and their symbiotic bacteria is consistent with results of an earlier study in which the question of a specific relationship between host and symbiont was examined from the perspective of genomic polymorphism in the symbiotic strains of each fish. Multiple strains of $P$. leiognathi were isolated from the light organ of each of several species of the fish and from multiple specimens of many of the examined species; no correlation was seen between the different strains, distinguished genomotypically by DNA fingerprinting, and the species of leiognathid fish from which they were isolated (Dunlap et al., 2004). This host species-independent genomotypic polymorphism of $P$. leiognathi suggested that evolutionary divergence of the bacteria is independent of that of the fishes, a finding confirmed here through phylogenetic analysis demonstrating the absence of codivergence.

The results presented here on fishes differ from those of a previous report on bacterially luminous squids in which an apparent congruence of the phylogenies of sepiolid squids and their symbiotic strains of $V$. fischeri was interpreted as evidence of "parallel evolution" (Nishiguchi et al., 1998). Our analysis of the results of that study and of data reported for squids and for luminous bacteria (Nishiguchi et al., 1998, 2004; Nishiguchi and Nair, 2003), however, revealed no convincing evidence of codivergence. We therefore conclude that "parallel evolution" does not characterize bioluminescent symbiosis between squids and luminous bacteria.

The absence of codivergence and strict host-family bacterial species specificity is not surprising given the general features of bioluminescent symbioses. In the majority of these associations, the bacteria are not obligately symbiotic; they colonize a variety of other marine habitats, including intestinal tracts, skin, and body fluids of marine animals, sediment and seawater, as typical members of commensal, saprophytic, pathogenic and free-living bacterial communities made up of many non-luminous, non-symbiotic bacteria (Baumann and Baumann, 1981; Hastings and Nealson, 1981; Dunlap and Kita-Tsukamoto, 2006). Possible exceptions to this lack of dependence might be the bioluminescent symbioses between unidentified luminous bacteria and anomalopid and certain ceratioid fishes; the bacteria in these associations have not been cultured under laboratory conditions and therefore might be obligately symbiotic (Hastings and Nealson, 1981; Haygood and Distel, 1993; Haygood, 1993; Dunlap and Kita-Tsukamoto, 2006). Phylogenetic analysis of three species of anomalopid fishes and their bacteria revealed, however, that the host and symbiont phylogenies are not congruent (Haygood, 1993). Consistent with the lack of exclusive dependence on the host, the bacteria colonizing light organs are acquired from the environment by the members of each new generation of the host (Wei and Young, 1989; McFall-Ngai and Ruby, 1991; Wada et al., 1999). This attribute means that light organs of different specimens of a given animal species could be colonized by different bacteria. Evidence confirming this possibility is reported recently for fishes (Kaeding et al., 2007) and was reported previously for squid (Fidopiastis et al., 1998; Nishiguchi, 2000), with two species of bacteria colonizing the same light organ (i.e., bacterial cosymbiosis), as well as by the finding here that different members of a given family of fishes harbor different species of luminous bacteria in their light organs. Furthermore, the animal requires no obvious biochemical or nutritional contribution from the bacteria for its growth or development, and the developmental program giving rise to the light organ and accessory tissues runs independently of the presence of the host's native bacteria (Claes and Dunlap, 2000). This "hard-wiring" of light-organ development indicates a significant biological independence of the animal from bacteria, native or otherwise, in formation of the attribute of the animal most central to symbiosis, the light organ and its accessory tissues. These general attributes make it difficult to envision the selection necessary for strict species specificity or codivergence to arise, as well as for the obligate dependence necessary to facilitate and select for coevolutionary changes.

It is evident from the results presented here that bacterial affiliations in bioluminescent symbioses are less specific than previously thought (e.g., Reichelt et al., 1977; Ruby and Morin, 1978; Hastings and Nealson, 1981; Dunlap and Kita-Tsukamoto, 2006). The instances reported here of different species within a host family harboring different species of light-organ bacteria 
(Figs 2 and 3), and instances of bacterial cosymbiosis (Fidopiastis et al., 1998; Nishiguchi, 2000; Kaeding et al., 2007; Figs 2 and 3), together with the lack of evidence for codivergence, led us to re-examine the extent to which a host family bacterial species specificity actually characterizes bioluminescent symbioses. To do so, we extended the sampling in this study and combined this additional information with data from the published literature, to more fully define the host species ranges of luminous bacteria. Because bacterial species identifications based solely on comparisons of phenotypic traits may be inaccurate (Ast and Dunlap, 2004, 2005; Dunlap and Ast, 2005), we included data only for those bacteria whose identifications were determined or confirmed by DNA-sequence criteria.

The assembled information (Table 2) revealed several instances in which host-symbiont affiliations cross taxonomic lines, either for the symbiotic bacteria or for the host animals. For example, many different kinds of fishes harbor a single species of bacteria, P. kishitanii, as noted above (Fig. 2). To further test the host range of $P$. kishitanii, we included here bacteria isolated from the light organs of opisthoproctids (Argentiniformes) from the Atlantic Ocean (Haygood et al., 1992; Haygood, 1993; M. Haygood, pers. comm.) and from light organs of additional species of chlorophthalmid and macrourid fishes from the Indian Ocean (Vydryakova et al., 1995; G. Vydryakova, pers. comm.). These bacteria were identified here as $P$. kishitanii based on the sequence of gyr $B$ and other genes. Together with the light-organ symbionts of opisthoproctids, those of the chlorophthalmid fishes, Chlorophthalmus acutifrons and C. nigromarginatus, and the macrourid fishes, Caelorinchus denticulatus, C. fasciatus, C. japonicus, C. kishinouyei, Malacocephalus laevis, Ventrifossa garmani and $V$. rhipidodorsalis, are newly reported here as members of $P$. kishitanii. The exceptionally wide host range of $P$. kishitanii, while not explicitly contradicting host family bacterial species specificity, is not consistent with the hypothesis of codivergence of fish and bacterium, which implies that different bacterial species would be symbiotic with different fish. The only obvious connection among the symbiotic hosts of $P$. kishitanii is a deep, cold habitat. Contrasting this pattern is the presence of $V$. fischeri in two species of macrourid, C. formosanus and $C$. multispinulosus, which we confirmed by analysis of the bacterial symbionts of a second fish specimen in each case. The specimens of $C$. multispinulosus were collected from waters of intermediate depth, 100-300 m. Preliminary observations indicate that $V$. fischeri is present, together with $P$. kishitanii, also in light organs of some specimens of the morid fish, Physiculus japonicus (Table 2), a species that migrates between shallow and deep waters. Other examples of host ranges that encompass distantly related hosts are seen for $P$. leiognathi and $V$. fischeri, each of which is symbiotic with both fishes and squids (Table 2). Further emphasizing the fact that host phylogeny does not correlate consistently with the species of bacterial symbiont, we have found an example of the same symbiont strain type, identical at the DNA sequence level for the various genes examined and at the DNA fingerprint level, in symbiosis with the beryciform fish, Monocentris japonicus, and the sepiolid squid, Euprymna morsei (P.V. Dunlap, J.C. Ast and M.M. Pearce, personal observation). The only obvious connection between these two host animals is collection location; they were both collected from shallow, coastal waters of Honshu, Japan, in the same local vicinity. Furthermore, numerous examples of cosymbiosis are listed, for acropomatid, leiognathid and morid fishes (Table 2) and for sepiolid squid (Fidopiastis et al., 1998; Nishiguchi, 2000). The inability of the host under natural conditions to discriminate between bacteria that are phylogenetically distinct directly contradicts strict host family bacterial species specificity.

Phylogenetic differences among bacterially bioluminescent fishes (Fig. 2) and the substantial differences in morphology and anatomical location of fish light organs (Herring and Morin, 1978) indicate that bioluminescent symbioses may have arisen independently in fishes multiple times (Haygood, 1993). To test this inference and better reveal the relationships of bacterially luminous fishes to other fishes, we examined here the COI gene sequences of a wide variety of fish species (Appendix D). The results of this analysis demonstrate that fishes bearing light organs colonized by luminous bacteria do not form a monophyletic group (Appendix D); bioluminescent symbioses evolved independently multiple times. Luminous bacterial symbionts therefore presumably have had the time, opportunity and potential selective pressures for divergence in concert with their host fishes. However, the patterns of symbionthost affiliation evident in nature (Fig. 2, Table 2), which reveal that fish family bacterial species specificity is often contradicted, indicate that fishes and symbiotic luminous bacteria have not evolved together in a way that correlates with phylogeny.

What then accounts for the patterns of symbiont-host taxonomic affiliation observed in nature? A meaningful explanation for these patterns must take into account the phylogenetic diversity of hosts harboring the same symbiont species (Fig. 2), the lack of strict bacterial specificity for a host clade (Table 2), the frequent occurrence of cosymbiosis (Table 2), as well as the likelihood of host switching (Fig. 4) and known physiological differences among luminous bacteria (Nealson, 1979; Hastings et al., 1987). We propose that environmental congruence of host and symbiont dictates to a large extent which symbiont species colonize a host animal. According to this hypothesis, the environmental location (i.e., geographic location and depth) where the 
aposymbiotic juvenile hosts hatch from the egg and are first exposed to ambient seawater, allowing their nascent light organs to become colonized by bacteria, is a critical factor. Environmental temperature, related to geographic location and depth, through its influence over the depths and geographic ranges of host animals, and its influence over the incidence and relative densities of potential symbionts in those waters at that time, therefore is likely to play a major role in defining the patterns of host-symbiont affiliation (Hastings and Nealson, 1981; Ast and Dunlap, 2005). Unfortunately, little is known about the reproductive and larval biology of coastal and bentho-pelagic fishes that would bear on the questions of where and when these fishes acquire their luminous symbionts or about the kinds and numbers of bacteria present in those waters at those times. Some experimental evidence (Fidopiastis et al., 1998; Nishiguchi, 2000), however, can be interpreted as supporting the environmental congruence hypothesis.

The geographic locations and depths at which the fishes and squid and their symbiotic bacteria (Table 2) typically occur also generally support the environmental congruence hypothesis (see Hastings and Nealson, 1981). Coastal shallow-dwelling $(0-150 \mathrm{~m})$ animals in temperate and tropical regions include the loliginid and sepiolid squids and the leiognathid and monocentrid fishes. These host animals typically harbor $P$. leiognathi or $V$. fischeri, which are relatively mesophilic bacteria. Sepiolid squids captured in deeper waters also harbor $V$. logei, a somewhat more psychrotrophic bacterium than $V$. fischeri (Fidopiastis et al., 1998; Nishiguchi, 2000). Deep ( $>250 \mathrm{~m}$ ), cold dwelling fishes (Froese and Pauly, 2004) typically harbor P. kishitanii, which is a more pyschrotrophic bacterium than the other species listed here. Fishes collected at intermediate depths, 100 $300 \mathrm{~m}$, harbor $V$. fischeri in the case of C. multispinulosis, or P. mandapamensis in the case of A. japonicum and $P$. panayensis. In at least two cases, however, the apparent depth/temperature relationship does not appear to hold up; G. jordani is recorded as a deep dwelling fish (Froese and Pauly, 2004), but it harbors $P$. mandapamensis, as does the shallow dwelling apogonid fish, Siphamia versicolor (Table 2). A possible explanation for this discrepancy is that the adult animal might occur and be captured in locations and at depths very different from where the aposymbiotic juveniles of that fish acquired their luminous symbionts. The pattern noted here and previously (Hastings and Nealson, 1981) between depth and the species of symbiont harbored by an adult host fish therefore may not correlate perfectly with the observed host range of a symbiont (Table 2), although it is strongly supported by data from nature and has substantial value for predicting the species of symbiont a fish or squid might harbor in its light organ, based on the location and depth from which the animal was captured.
It is important to note that the environmental congruence hypothesis includes the observation that non-luminous bacteria apparently do not establish themselves in fish and squid light organs. A level of selection is likely to be involved, but with the commonality among the colonizing (i.e., selected) bacteria apparently being luminescence, regardless of species, as intimated several years ago by Reichelt et al. (1977). Selection against non-luminous bacteria would exclude the majority of bacteria from taking up residence in the fish's nascent light organ; the successful colonizers are likely to be those species of luminous bacteria that are locally abundant and physiologically adapted to conditions where the fish or squid eggs hatch out as aposymbiotic juveniles. Furthermore, environmental congruence does not exclude the possibility of a geographically isolated host species developing a more exclusive interaction with one kind of luminous bacterium. This postulated greater exclusivity could arise, for example, through genetic drift in a geographically isolated host species that is interacting with a limited diversity of potential symbionts.

The evolutionary (genetic) adaptations for bioluminescent symbiosis, i.e., presence of light organs that can be colonized by luminous bacteria, accessory tissues for controlling, diffusing and shaping the emission of light, and behaviors associated with light emission, all are borne by the animal. Are there genetic adaptations in the bacteria that are necessary for and specific to their existence in light organs compared with the other habitats they colonize? None so far have been identified or inferred. In the absence of compelling evidence of such specific adaptations, a view more parsimonious than coevolution is that light-organ symbiotic bacteria are opportunistic colonizers, able to persist in animal light organs as well as in a variety of other habitats to which they are adapted. Bioluminescent symbioses therefore appear to represent a paradigm of symbiosis that differs fundamentally from associations involving obligate, intracellular, maternally transferred endosymbionts. While fishes and squids are dependent ecologically on luminous bacteria, the bacteria are not obligately dependent on their bioluminescent hosts. Bioluminescent symbioses therefore appear to be shaped by selection in the animal for light emission, with the species of luminous bacteria occurring as light-organ symbiont of a given species of fish or squid determined in large part by environmental distributions of the different species of luminous bacteria.

\section{Acknowledgments}

We thank the following individuals for assistance collecting fish specimens: Y. Iwatsuki, University of Miyazaki; H. Imai and H. Ishimori, University of the 
Ryukyus; C. Lavilla-Pitogo, SEAFDEC, Philippines; J. Ledesma, Tigbauan, Philippines; T. Hosoda and the captain and crew of $\mathrm{T} / \mathrm{V}$ Hokuto, Tokai University; A. Makihara, captain of the fishing vessel Kotobukimaru, Owase, Japan; A. Iwata, Mie Prefecture Office, Owase, Japan; K. Yamahashi, Odawara City Fish Market; H. Senou, Kanagawa Prefectural Museum of Natural History; Y. Machida, Kochi University; and $\mathrm{Y}$. Tachibana and the captain and crew of the $\mathrm{T} / \mathrm{S}$ Seisui-maru, Mie University. T.-I. Chen and J.-H. Cheng provided accommodations at the Tungkang Marine Laboratory, Taiwan Fisheries Research Institute. We thank A. Gorog, University of Michigan, for drawing the map of Asia. T. Tsuchiya, Tokai University, and A. Kaeding, K. Davis, and H. Urbanczyk, University of Michigan, provided technical assistance. H. Urbanczyk provided comments on the manuscript and helpful advice. We thank M. Haygood, Oregon Graduate Institute, Beaverton, Oregon, for the gift of bacterial strains from light organs of opisthoproctid fishes from the mid East Atlantic Ocean, and G. Vydryakova, Institute of Biophysics, Krasnoyarsk, Russia, for the gift of genomic DNA of bacterial strains from light organs of chlorophthalmid and macrourid fishes from the Indian Ocean. DNA sequencing was carried out by staff of the University of Michigan Sequencing Core. This work was supported by grant DEB 0413441 from the National Science Foundation (to P.V.D.) and by the Multilateral Cooperative Research Program of the Japan Society for the Promotion of Science (Coastal Oceanography) (to S.K.).

\section{References}

Ast, J.C., Dunlap, P.V., 2004. Phylogenetic analysis of the lux operon distinguishes two evolutionarily distinct clades of Photobacterium leiognathi. Arch. Microbiol. 181, 352-361.

Ast, J.C., Dunlap, P.V., 2005. Phylogenetic resolution and habitat specificity of members of the Photobacterium phosphoreum species group. Environ. Microbiol. 7, 1641-1654.

Bardey, V., Vallet, C., Robas, N., Charpentier, B., Thouvenot, B., Mougin, A., Hajnsdorf, E., Regnier, P., Springer, M., Branlant, C., 2005. Characterization of the molecular mechanisms involved in the differential production of erythrose-4-phosphate dehydrogenase, 3-phosphoglycerate kinase and class II fructose-1,6-bisphosphate aldolase in Escherichia coli. Mol. Microbiol. 57, 1265-1287.

Baumann, P., Baumann, L., 1981. The marine Gram-negative eubacteria: genera Photobacterium, Beneckea, Alteromonas, Pseudomonas, and Alcaligenes. In: M.P. Starr, H. Stolp, H.G. Trüper, A. Balows, H.G. Schlegel (Eds.), The Prokaryotes: a Handbook on Habitats, Isolation, and Identification of Bacteria. Springer-Verlag, Berlin, pp. 1302-1331.

Baumann, P., Baumann, L., Lai, C.-Y., Rouhbakhsh, 1995. Genetics, physiology, and evolutionary relationships of the genus Buchnera: intracellular symbionts of aphids. Annu. Rev. Microbiol. 49, 55-94.

Boisvert, H., Chatelain, R., Bassot, J.M., 1967. Étude d'un Photobacterium isolé de l'organe lumineux des poissons Leiognathidae. Ann. Inst. Pasteur (Paris), 112, 520-524.
Boschi-Muller, S., Azza, S., Pollastro, D., Corbier, C., Branlant, G., 1997. Comparative enzymatic properties of GapB-encoded erythrose-4-phosphate dehydrogenase of Escherichia coli and phosphorylating glyceraldehyde-3-phsosphate dehydrogenase. J. Biol. Chem. 272, 15106-15112.

Cary, S.C., Giovanonni, S.J., 1993. Transovarial inheritance of endosymbiotic bacteria in clams inhabiting deep-sea hydrothermal vents and cold seeps. Proc. Natl Acad. Sci USA. 90, 5695-5699.

Charleston, M.A., 1998. Jungles: a new solution to the host-parasite phylogeny reconciliation problem. Math. Biosci. 149, 191-223.

Charleston, M.A., Page, R.D.M., 2002. Treemap, Version 2.0. Available from the authors at: http://taxonomy.zoology.gla. ac.uk/ mac/treemap/index.html

Charleston, M.A., Perkins, S.L., 2006. Traversing the tangle: algorithms and applications for cophylogenetic studies. J. Biomed. Informat. 39, 62-71.

Claes, M.F., Dunlap, P.V., 2000. Aposymbiotic culture of the sepiolid squid Euprymna scolopes: role of the symbiotic bacterium Vibrio fischeri in host animal growth, development, and light organ morphogenesis. J. Exp. Zool. 286, 280-296.

Dunlap, P.V., 1984. Physiological and morphological state of the symbiotic bacteria from light organs of ponyfish. Biol. Bull. 167, 410-425.

Dunlap, P.V., 1985. Physiological and morphological state of the symbiotic bacteria from light organs of ponyfish. Biol. Bull. 167, 410-425.

Dunlap, P.V., Ast, J.C., 2005. Genomic and phylogenetic characterization of the luminous bacteria symbiotic with the deep-sea fish Chlorophthalmus albatrossis (Aulopiformes: Chlorophthalmidae). Appl. Environ. Microbiol. 71, 930-939.

Dunlap, P.V., Jiemjit, A., Ast, J.C., Pearce, M.M., Marques, R.R., Lavilla-Pitogo, C.R., 2004. Genomic polymorphism in symbiotic populations of Photobacterium leiognathi. Environ. Microbiol. 6, 145-158.

Dunlap, P.V., Kita-Tsukamoto, K., 2006. Luminous bacteria. In: M. Dworkin, S. Falkow, E. Rosenberg, K.-H. Schleifer, E. Stackebrandt (Eds.), The Prokaryotes, a Handbook on the Biology of Bacteria, 3rd edn, Vol. 2. Springer, New York, pp. 863-892.

Fidopiastis, P.M., von Boletzky, S., Ruby, E.G., 1998. A new niche for Vibrio logei, the predominant light organ symbiont of squids in the genus Sepiola. J. Bacteriol. 180, 59-64.

Froese, R., Pauly, D. (Eds.), 2004. FishBase, Ver. 04. Published online. http://www.fishbase.org.

Fukasawa, S., Dunlap, P.V., 1986. Identification of luminous bacteria isolated from the light organs of the squid, Doryteuthis kensaki. Agri. Biol. Chem. 50, 1645-1646.

Goloboff, P.A., Farris, J.S., Nixon, K.C., 2005. TNT: Tree Analysis Using New Technology, Version 1.0. Distributed by the authors.

Graf, J., Ruby, E.G., 1998. Host-derived amino acids support the proliferation of symbiotic bacteria. Proc. Natl Acad. Sci. USA. 95, $1818-1822$.

Hastings, J.W., 1971. Light to hide by: ventral luminescence to camouflage the silhouette. Science, 173, 1016-1017.

Hastings, J.W., Makemson, J., Dunlap, P.V., 1987. How are growth and luminescence regulated independently in light organ symbionts? Symbiosis, 4, 3-24.

Hastings, J.W., Nealson, K.H., 1981. The symbiotic luminous bacteria. In: M.P. Starr, H. Stolp, H.G. Trüper, A. Balows, H.G. Schlegel (Eds.), The Prokaryotes: a Handbook on Habitats, Isolation, and Identification of Bacteria. Springer-Verlag, Berlin, pp. 1332-1345.

Haygood, M.G., 1993. Light organ symbioses in fishes. Crit. Rev. Microbiol. 19, 191-216.

Haygood, M.G., Distel, D.L., 1993. Bioluminescent symbionts of flashlight fishes and deep-sea anglerfishes form unique lineages related to the genus Vibrio. Nature 363, 154-156.

Haygood, M.G., Distel, D.L., Herring, P.J., 1992. Polymerase chain reaction and $16 \mathrm{~S}$ rRNA gene sequences from the luminous 
bacterial symbionts of two deep-sea anglerfishes. J. Mar. Biol. Assoc. UK, 71, 149-159.

Haygood, M.G., Tebo, B.M., Nealson, K.H., 1984. Luminous bacteria of a monocentrid fish (Monocentris japonicus) and two anomalopid fishes (Photoblepharon palpebratus and Kryptophaneron alfredi): population sizes and growth within the light organs, and rates of release into the seawater. Mar. Biol. 78, 249-254.

Herring, P.J., Morin, J.G., 1978. Bioluminescence in fishes. In: P.J. Herring (Ed.), Bioluminescence in Action. Academic Press, London, pp. 273-329.

Hosokawa, T., Kikuchi, Y., Nikoh, N., Shimada, M., Fukatsu, T., 2006. Strict host-symbiont cospeciation and reductive genome evolution in insect gut bacteria. PLoS Biol. 4, e337.

Jackson, A.P., 2004. A reconciliation analysis of host switching in plant-fungal symbioses. Evolution 58, 1909-1923.

Jones, B.W., Lopez, J.E., Huttenburg, J., Nishiguchi, M.K., 2006. Population structure between environmentally transmitted vibrios and bobtail squids using nested clade analysis. Mol. Ecol. 15, 43174329.

Jones, B.W., Nishiguchi, M.K., 2004. Counterillumination in the Hawaiian bobtail squid, Euprymna scolopes Berry (Mollusca: Cephalopoda). Mar. Biol. 144, 1151-1155.

Kaeding, A.J., Ast, J.C., Pearce, M.M., Urbanczyk, H., Kimura, S., Endo, H., Nakamura, M., Dunlap, P.V., 2007. Phylogenetic specificity and diversity in the bioluminescent symbioses of Photobacterium mandapamensis. Appl. Environ. Microbiol. 73, 3173-3182.

Kimura, S., Dunlap, P.V., Peristiwady, T., Lavilla-Pitogo, C.R., 2003. The Leiognathus aureus complex (Perciformes: Leiognathidae), with the description of a new species. Ichthyol. Res. 50, 221-232.

Lo, N., Bandi, C., Watanabe, H., Nalepa, C., Beninati, C., 2003. Evidence for cocladogenesis between diverse dictyopteran lineages and their intracellular endosymbionts. Mol. Biol. Evol. 20, 907-913.

Maddison, D.R., Maddison, W.P., 2005. Macclade4: Analysis of Phylogeny and Character Evolution, Version 4.08. Sinauer Associates, Sunderland, MA.

McFall-Ngai, M.J., 1991. Luminous bacterial symbiosis in fish evolution: adaptive radiation among the leiognathid fishes. In: L. Margulis, R. Fester (Eds.), Symbiosis as a Source of Evolutionary Innovation: Speciation and Morphogenesis, 2nd edn. MIT Press, Cambridge, MA, pp. 381-409.

McFall-Ngai, M.J., Dunlap, P.V., 1983. Three new modes of luminescence in the leiognathid fish Gazza minuta: discrete projected luminescence, ventral body flash, and buccal luminescence. Mar. Biol. 73, 227-237.

McFall-Ngai, M.J., Morin, J.G., 1991. Camouflage by disruptive illumination in leiognathids, a family of shallow-water, bioluminescent fishes. J. Exp. Biol. 156, 119-137.

McFall-Ngai, M.J., Ruby, E.G., 1991. Symbiont recognition and subsequent morphogenesis as early events in an animal-bacterial mutualism. Science, 254, 1491-1494.

Miya, M., Kawaguchi, A., Nishida, M., 2001. Mitogenomic exploration of higher teleostean phylogenies: a case study for moderatescale evolutionary genomics with 38 newly determined complete mitochondrial DNA sequences. Mol. Biol. Evol. 18, 1993-2009.

Miya, M., Takeshima, H., Endo, H., Ishiguro, N.B., Inoue, J.G., Mukai, T., Satoh, T.P., Yamaguchi, M., Kawaguchi, A., Mabuchi, K., Shirai, S.M., Nishida, M., 2003. Major patterns of higher teleostean phylogenies: a new perspective based on 100 complete mitochondrial DNA sequences. Mol. Phylogenet. Evol. 26, 121-138.

Morin, J.G., Harrington, A., Nealson, K., Krieger, N., Baldwin, T.O., Hastings, J.W., 1975. Light for all reasons: versatility in the behavioral repertoire of the flashlight fish. Science, 190, 74-76.

Nakabo, T. (Ed.), 2002. Fishes of Japan with Pictoral Keys to the Species. Tokai University Press, Tokyo, Japan.

Nealson, K.H., 1978. Isolation, identification and manipulation of luminous bacteria. Methods Enzymol. 57, 153-166.
Nealson, K.H., 1979. Alternative strategies of symbiosis of marine luminous fishes harboring light-emitting bacteria. Trends Biochem. Sci. 4, 105-110.

Nealson, K., Cohn, D., Leisman, G., Tebo, B., 1981. Coevolution of luminous bacteria and their eukaryotic hosts. Ann. New York Acad. Sci. 361, 76-91.

Nealson, K.H., Haygood, M.G., Tebo, B.M., Roman, M., Miller, E., McCosker, J.E., 1984. Contribution of symbiotically luminous fishes to the occurrence and bioluminescence of luminous bacteria in seawater. Microb. Ecol. 10, 69-77.

Nelson, J.S., 2006. Fishes of the World, 4th edn. John Wiley and Sons, New York.

Nishiguchi, M., 2000. Temperature affects species distribution in symbiotic populations of Vibrio spp. Appl. Environ. Microbiol. 66, 3550-3555.

Nishiguchi, M.K., Lopez, J.E., von Boletzky, S., 2004. Enlightenment of old ideas from new investigations: the evolution of bacteriogenic light organs in squids. Evol. Dev. 6, 41-49.

Nishiguchi, M., Nair, V.S., 2003. Evolution of symbiosis in the Vibrionaceae: a combined approach using molecules and physiology. Int. J. System. Evol. Microbiol. 53, 2019-2026.

Nishiguchi, M., Ruby, E.G., McFall-Ngai, M.J., 1998. Competitive dominance among strains of luminous bacteria provides an unusual form of evidence for parallel cladogenesis in sepiolid squid-Vibrio symbioses. Appl. Environ. Microbiol. 64, 3209-3213.

Page, R.D.M., 1994. Parallel phylogenies: reconstructing the history of host-parasite assemblages. Cladistics 10, 155-173.

Page, R.D.M., Charleston, M.A., 1998. Trees within trees: phylogeny and historical associations. Trends Ecol. Evol. 13, 356-359.

Peek, A.S., Feldman, R.A., Lutz, R.A., Vrijenhoek, R.C., 1998. Cospeciation of bacteria and deep sea clams. Proc. Natl Acad. Sci. USA. 95, 9962-9966.

Reichelt, J.L., Nealson, K., Hastings, J.W., 1977. The specificity of symbiosis: Ponyfish and luminous bacteria. Arch. Microbiol. 112, 157-161.

Ruby, E.G., Asato, L.M., 1993. Growth and flagellation of Vibrio fischeri during initiation of the sepiolid squid light organ symbiosis. Arch. Microbiol. 159, 160-167.

Ruby, E.G., Morin, J.G., 1978. Specificity of symbiosis between deepsea fish and psychrotrophic luminous bacteria. Deep-Sea Res. 25, $161-171$.

Saffo, M.B., 2002. Themes from variation: probing the commonalities of symbiotic associations. Integr. Comp. Biol. 42, 291-294.

Sasaki, A., Ikejima, K., Aoki, S., Azuma, N., Kashimura, N., Wada, M., 2003. Field evidence for bioluminescent signaling in the pony fish, Leiognathus elongatus. Environ. Biol. Fishes, 66, 307-311.

Shimizu, T., 1997. Beryciformes. In: O. Okamura, K. Amaoka (Eds.), Sea Fishes of Japan. Yama-Kei Publishers Co., Ltd, Tokyo, pp. 156-167.

Sparks, J.S., Dunlap, P.V., Smith, W.L., 2005. Evolution and diversification of a sexually dimorphic luminescent system in ponyfishes (Teleostei: Leiognathidae), including diagnoses for two new genera. Cladistics 21, 305-327.

Swofford, D.L., 2002. PAUP*: Phylogenetic Analysis Using Parsimony (*and Other Methods), Version 4.0B10. Sinauer Associates, Sunderland, MA.

Thompson, J.N., 2005. The Geographic Mosaic of Coevolution. University of Chicago Press, Chicago, IL.

Vydryakova, G.A., Kuznetsov, A.M., Primakova, G.A., Chugaeva, Y.V., Fish, A.M., 1995. Luminescent bacterial symbionts and commensals of luminescent and nonluminescent animals of the Indian Ocean. Mikrobiologiya 64, 589-592.

Wada, M., Azuma, N., Mizuno, N., Kurokura, H., 1999. Transfer of symbiotic luminous bacteria from parental Leiognathus nuchalis to offspring. Mar. Biol. 135, 683-687.

Wada, M., Kamiya, A., Uchiyama, N., Yoshizawa, S., KitaTsukamoto, K., Ikejima, K., Yu, R., Imada, C., Karatani, H., Mizuno, N., Suzuki, Y., Nishida, M., Kogure, K., 2006. LuxA gene 
of light organ symbionts of the bioluminescent fish Acropoma japonicum (Acropomatidae) and Siphamia versicolor (Apogonidae) forms a lineage closely related to that of Photobacterium leiognathi ssp. mandapamensis. FEMS Microbiol. Lett. 260, 186-192.

Wei, S.L., Young, R.E., 1989. Development of symbiotic bacterial bioluminescence in a nearshore cephalopod, Euyprmna scolopes. Mar. Biol. 103, 541-546.

Wheeler, W., Gladstein, D., De Laet, J., 2003. POY, Phylogeny Reconstruction Via Optimization of DNA and Other Data, Version 3.0.11 (American Museum of Natural History, New
York), available by anonymous ftp from ftp://ftp.amnh.org/pub/ people/wheeler/poy/version3-current/poy.3.0.11.pdf.

Wolfe, C.J., Haygood, M.G., 1991. Restriction fragment length polymorphism analysis reveals high levels of genetic divergence among the light organ symbionts of flashlight fish. Biol. Bull. 181, 135-143.

Woodland, D.J., Cabanban, A.S., Taylor, V.M., Taylor, R.J., 2002. A synchronized rhythmic flashing light display by schooling Leiognathus splendens (Leiognathidae: Perciformes). Mar. Freshwater Res. 53, 159-162.

\section{Appendix A}

GenBank accession numbers

\begin{tabular}{|c|c|c|c|c|}
\hline Fish specimen & $16 \mathrm{~S}$ & $\mathrm{COI}$ & $\mathrm{H} 3$ & $28 \mathrm{~S}$ \\
\hline Chlorophthalmus acutifrons Cacut.1 (D-0158) & DQ648417 & DQ648439 & - & - \\
\hline Chlorophthalmus albatrossis Calba.3 (D-0140) & DQ648418 & DQ648440 & - & - \\
\hline Chlorophthalmus nigromarginatus Cnigro.1 (D-0174) & DQ648419 & DQ648441 & - & - \\
\hline Caelorinchus formosanus Cform.1 (D-0190) & DQ648421 & DQ648443 & - & - \\
\hline Caelorinchus hubbsi Chubb.1 (D-0146) & DQ648422 & DQ648444 & - & - \\
\hline Caelorinchus japonicus Cjapo.1 (D-0176) & DQ648423 & DQ648445 & - & - \\
\hline Caelorinchus multispinulosis Cmult.1 (D-0237) & DQ648426 & DQ648448 & - & - \\
\hline Ventrifossa garmani Vgarm.1 (D-0155) & DQ648433 & DQ648455 & - & - \\
\hline Ventrifossa longibarbata Vlong.1 (D-0143) & DQ648434 & DQ648456 & - & - \\
\hline Ventrifossa rhipidodorsalis Vrhip.1 (D-0202) & DQ648435 & DQ648457 & - & - \\
\hline Gadella jordani Gjord.1 (D-0188) & DQ648427 & DQ648449 & - & - \\
\hline Physiculus japonicus Pjapo.2 (D-0069) & DQ648431 & DQ648453 & - & - \\
\hline Gazza minuta Gminu.9 (D-0030) & DQ648428 & DQ648450 & - & - \\
\hline Leiognathus equulus Lequu.16 (D-0184) & DQ648429 & DQ648451 & - & - \\
\hline Leiognathus fasciatus $(\mathrm{L} 16) \S$ & DQ027949 & DQ028019 & DQ028125 & DQ028216 \\
\hline “Leiognathus" jonesi Ljone.1 (LJ1p) & AY541656 & AY541631 & - & - \\
\hline "Leiognathus" nuchalis (LN1J) & AY541658 & AY541633 & DG028139 & DQ028230 \\
\hline “Leiognathus" philippinus Lphil.1 (LP1P) & AY541660 & AY541635 & DQ028140 & DQ028231 \\
\hline "Leiognathus" splendens $(\mathrm{LS} 2 \mathrm{P}) \S$ & AY541662 & AY541637 & DQ028142 & DQ028233 \\
\hline Photopectoralis bindus Lbind.1 (LB1P) & AY541651 & AY541626 & DQ028146 & DQ028237 \\
\hline Photopectoralis panayensis Ppana. $1(\mathrm{LH} 1 \mathrm{P}) \dagger$ & AY541659 & AY541634 & DQ028147 & DQ028238 \\
\hline Photoplagios elongatus (LE1J) $\$$ & AY541652 & AY541627 & DQ028149 & DQ028240 \\
\hline Photoplagios leuciscus ("Mad")§ & DQ027964 & DQ028034 & DQ028150 & DQ028241 \\
\hline Photoplagios rivulatus Lrivu.17 (LR1J) & AY541661 & AY541636 & DQ028154 & DQ028245 \\
\hline Photoplagios stercorarius Lster.1 (LST1P)† & AY541663 & AY541638 & DQ028155 & DQ028246 \\
\hline
\end{tabular}

*D-XXXX numbers are specimen tag numbers.

$\dagger$ Different specimen, but from same species and collection event as specimen used for bacterial isolation.

¥Different specimen and different collection event, but same species and collection location as specimen used for bacterial isolation.

$\S$ Same species, but different specimen, collection event, and location from specimen used for bacterial isolation.

\begin{tabular}{llll}
\hline Bacterial strain & gyrB & recA & lux \\
\hline cacut.1.1 & DQ648291 & DQ648380 & DQ648335 \\
cacut.1.2 & DQ648292 & DQ648381 & DQ648336 \\
calba.3.1 & AY642176 & DQ648382 & AY642200 \\
calba.3.2 & AY642177 & DQ648383 & AY642201 \\
\hline
\end{tabular}




\begin{tabular}{|c|c|c|c|}
\hline Bacterial strain & $\operatorname{gyr} B$ & $\operatorname{rec} A$ & $\operatorname{lu} x$ \\
\hline cnigro.1.2 & DQ648302 & DQ648395 & DQ648346 \\
\hline canat.1.4 & DQ648293 & DQ648385 & DQ648337 \\
\hline cform.1.1 & DQ648281 & DQ648372 & DQ648325 \\
\hline cform.1.2 & DQ648282 & DQ648373 & DQ648326 \\
\hline chubb.1.2 & DQ648294 & DQ648386 & DQ648338 \\
\hline cjapo.1.2 & DQ648297 & DQ648389 & DQ648341 \\
\hline ckamo.4.2 & AY849457 & DQ648390 & AY849508 \\
\hline ckamo.4.5 & DQ648298 & DQ648391 & DQ648342 \\
\hline ckish.1.1 & DQ648299 & DQ648392 & DQ648343 \\
\hline ckish.1.2 & DQ648300 & DQ648393 & DQ648344 \\
\hline cmult.1.1 & DQ648283 & DQ648374 & DQ648327 \\
\hline vlong.1.2 & DQ648306 & DQ648401 & DQ648350 \\
\hline vrhip.1.1 & DQ648307 & DQ648402 & DQ648351 \\
\hline vrhip.1.2 & DQ648308 & DQ648403 & DQ648352 \\
\hline gjord.1.1 & DQ371353 & DQ648411 & DQ371380 \\
\hline gjord.1.5 & DQ371355 & DQ648412 & DQ371382 \\
\hline pjapo.2.1 & AY849472 & DQ648396 & AY849523 \\
\hline pjapo. 2.2 & DQ648303 & DQ648397 & DQ648347 \\
\hline apros. 3.2 & DQ648289 & DQ648378 & DQ648333 \\
\hline apros.3.3 & DQ648290 & DQ648379 & DQ648334 \\
\hline mјаро.7.1 & DQ648285 & DQ648370 & DQ648329 \\
\hline mjapo.7.2 & DQ648286 & DQ648371 & DQ648330 \\
\hline ahane.1.1 & DQ648287 & DQ648376 & DQ648331 \\
\hline ahane.1.2 & DQ648288 & DQ648377 & DQ648332 \\
\hline lnuch.2.1 & DQ648319 & - & DQ648362 \\
\hline lphil.1.1 & DQ648320 & - & DQ648363 \\
\hline ATCC $25521^{\mathrm{T}}$ & AY455879 & - & M63594 \\
\hline lelon.2.1 & DQ652566 & - & DQ652567 \\
\hline lleuc.1.1 & AY455882 & - & DQ648361 \\
\hline lrivu.17.1 & DQ648321 & - & DQ648364 \\
\hline lster.2.1 & DQ648322 & - & DQ648365 \\
\hline lbind.1.1 & DQ648316 & - & DQ648356 \\
\hline ppana.3.2 & DQ371346 & - & DQ371373 \\
\hline ppana. 3.3 & DQ371357 & - & DQ371384 \\
\hline sinsi.1.2 & DQ648323 & - & DQ648366 \\
\hline smega.4.1 & DQ648313 & DQ648409 & DQ648367 \\
\hline smega.4.2 & DQ648314 & DQ648410 & DQ648368 \\
\hline ATCC $14126^{\mathrm{T}}$ & DQ648280 & DQ648369 & DQ648324 \\
\hline
\end{tabular}

\section{Appendix B: Parsimony analysis of statically aligned fish sequence data}

Fish sequence data used in direct optimization analysis were analyzed here with static alignment and parsimony. For the broad-scale analysis, the data were aligned by eye for the 16S rRNA gene, which resulted in an aligned length of $616 \mathrm{bp}$, and by inferred amino acid sequence for mitochondrial COI, which resulted in an aligned length of $658 \mathrm{bp}$. Gaps were treated as missing data, and the several regions of the 16S rRNA gene 

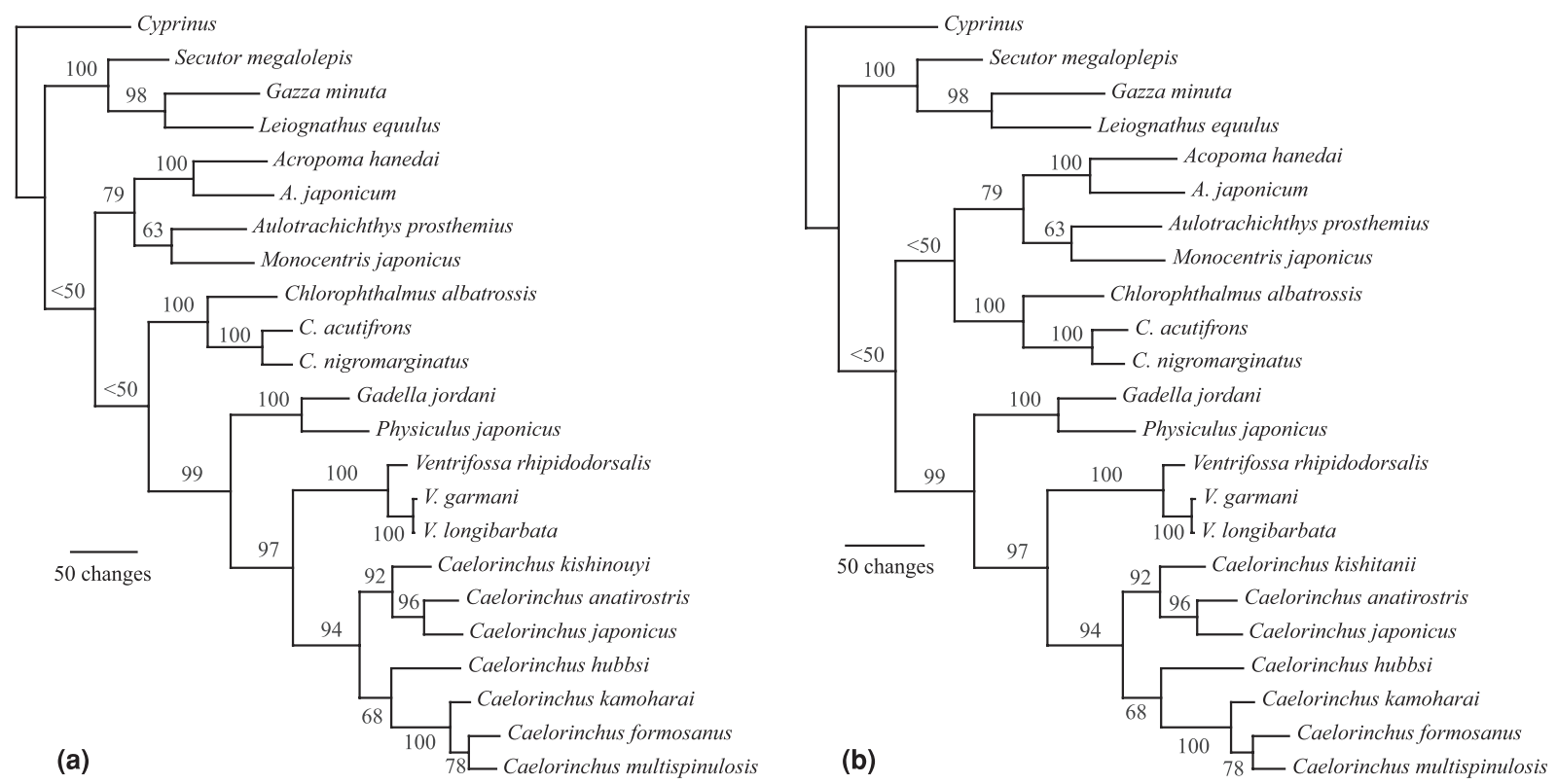

Fig. 5. Static alignment analysis of sequence data for the broad-scale fish analysis. Shown here are the two equally most parsimonious hypotheses of host fish relationships resulting from parsimony analysis of the mitochondrial $16 \mathrm{~S}$ rRNA and COI genes. Regions difficult to align were excluded, and gaps were treated as missing data (386 informative characters, length $=1725, \mathrm{CI}=0.39, \mathrm{RI}=0.57$ ). Jackknife percentages are at nodes. Statistics for the phylogeny of the symbionts of these fish are: length $=1757, \mathrm{CI}=0.71, \mathrm{RI}=0.94$ (Fig. 2 ); when the symbiont phylogeny was constrained to match these phylogenies, the statistics of the symbiont phylogeny are: (a) length $=3891$, CI $=0.32, \mathrm{RI}=0.69$; (b) length $=3880$, $\mathrm{CI}=0.32, \mathrm{RI}=0.69$.
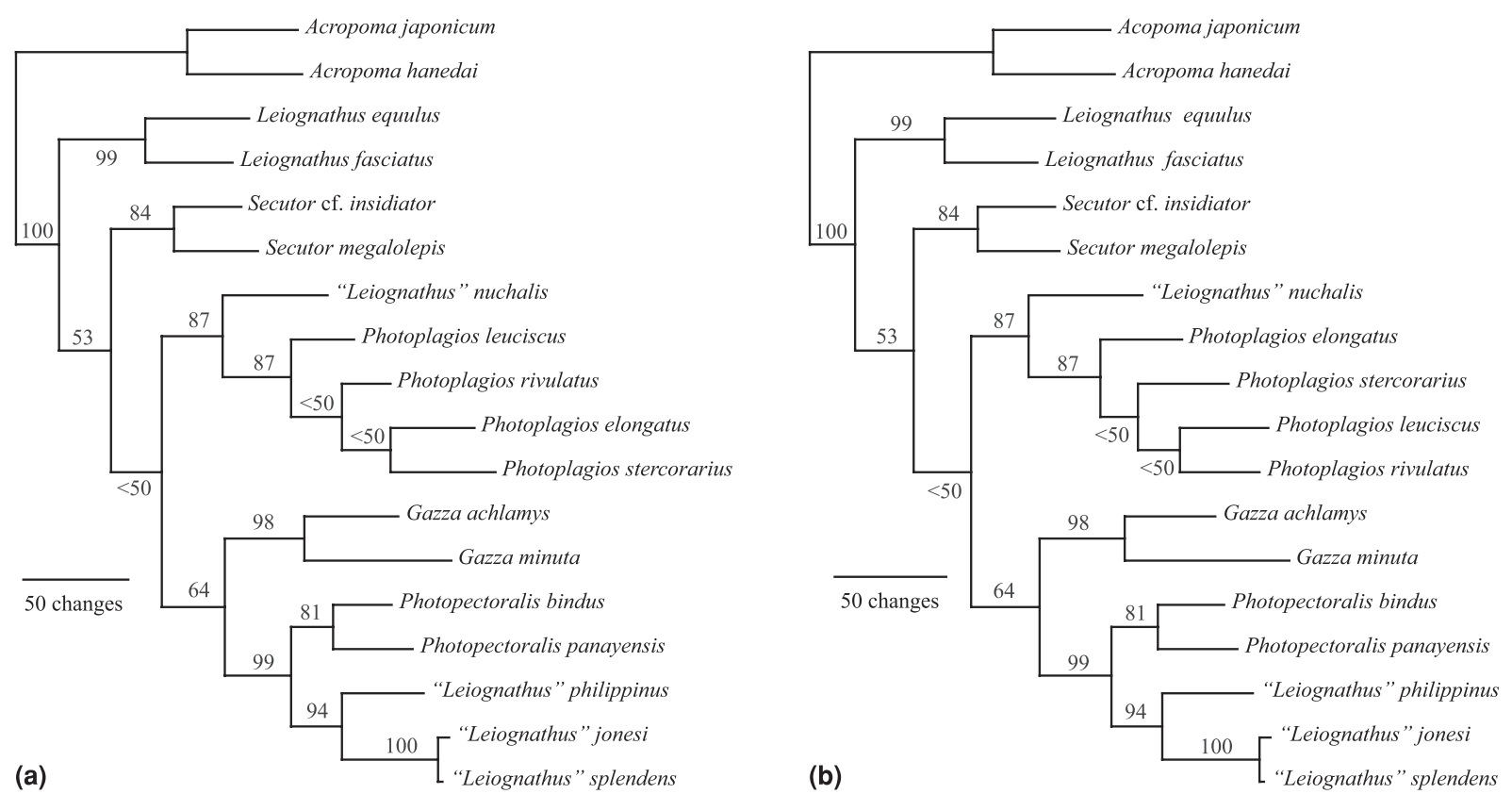

Fig. 6. Static alignment analysis of sequence data for the fine-scale (leiognathid) fish analysis. Shown here are the two equally most parsimonious hypotheses of leiognathid fish relationships resulting from parsimony analysis of the mitochondrial 16S rRNA, mitochondrial COI, nuclear histone $\mathrm{H} 3$, and nuclear 28S rRNA genes (324 informative characters, length $=1270, \mathrm{CI}=0.45, \mathrm{RI}=0.47$ ). Gaps were treated as missing data, and regions difficult to align in the 16S and 28S rRNA genes were excluded. Jackknife percentages are at nodes. Statistics for the phylogeny of the symbionts of these fish are: length $=1004, \mathrm{CI}=0.76, \mathrm{RI}=0.85$ (Fig. 3); when the symbiont phylogeny was constrained to match these phylogenies, the statistics of the symbiont phylogeny are: (a) length $=2054, \mathrm{CI}=0.37, \mathrm{RI}=0.22$; (b) length $=2053, \mathrm{CI}=0.37, \mathrm{RI}=0.22$. 
difficult to align were excluded from the analysis. Parsimony analysis (see Materials and methods for details) of the resulting 386 informative characters in the combined data set resulted in two equally most parsimonious hypotheses, both of which are presented here (Fig. 5a,b). These hypotheses differ somewhat from the direct optimization hypothesis, but the major clades resolved and the majority of the relationships were the same. Constraining the symbiont hypothesis to match either of these two hypotheses resulted in tree lengths that are more than twice as long as the most parsimonious symbiont trees, as did constraining the symbiont trees to match the direct optimization results (see Results for comparison).

For the fine-scale analysis, the $16 \mathrm{~S}$ and $28 \mathrm{~S}$ rRNA gene fragments were aligned by eye, and the protein coding genes for COI and histone $\mathrm{H} 3$ were aligned by inferred amino acid sequence. The manually aligned lengths of the fragments were $573 \mathrm{bp}$ (16S rRNA gene), $632 \mathrm{bp}$ (COI gene), $333 \mathrm{bp}$ (histone $\mathrm{H} 3$ gene), and 679 bp (28S rRNA gene). Gaps were treated as missing data, and several regions of the 16S and 28S rRNA genes were excluded from analysis because of alignment difficulties. Parsimony analysis (see Materials and methods for details) of the 324 informative characters in the combined data set resulted in two equally most parsimonious hypotheses, both of which are presented here (Fig. 6a,b); each differed somewhat from the hypotheses favored by direct optimization analysis, but the major clades resolved and the majority of the relationships were the same. Constraining the symbiont trees to match the fish trees resulted in tree lengths more than twice that of the most parsimonious symbiont trees, with lowered statistics of character fit to trees; these results are similar to the direct optimization results (see Results for comparison).

\section{Appendix C: TreeMap statistics and jungles without host switches}

This appendix presents a list of statistics from all the jungles generated by the TreeMap analysis of the original symbiont trees of Nishiguchi et al. (1998) and the reanalyzed symbiont tree (see Fig. 4 in main text). Jungles that require no host switching are presented in Fig. 7. In the list of jungle statistics, jungles shown in Fig. 4 are marked with a dagger, while jungles shown in Fig. 7 are marked with an asterisk. Significance values are based on randomization tests. See Material and methods for TreeMap settings for all analyses.

\begin{tabular}{|c|c|c|c|c|c|c|c|}
\hline $\begin{array}{l}\text { Figure } \\
\text { no. }\end{array}$ & $\begin{array}{l}\text { Jungle } \\
\text { no. }\end{array}$ & Co-divergences & Duplications & Loss & $\begin{array}{l}\text { Host } \\
\text { switches }\end{array}$ & $\begin{array}{l}\text { Total } \\
\text { cost }\end{array}$ & $P$-value \\
\hline $4 \mathrm{~b}$ & $* \dagger 1$ & 10 & 0 & 0 & 0 & 0 & $0.0020 \pm 0.0010$ \\
\hline \multirow[t]{8}{*}{$4 c$} & 1 & 4 & 6 & 0 & 3 & 9 & $0.67 \pm 0.015$ \\
\hline & 3 & 4 & 6 & 0 & 3 & 9 & $0.68 \pm 0.015$ \\
\hline & 4 & 4 & 6 & 0 & 3 & 9 & $0.67 \pm 0.015$ \\
\hline & 5 & 6 & 4 & 1 & 2 & 7 & $0.47 \pm 0.016$ \\
\hline & 8 & 6 & 4 & 1 & 2 & 7 & $0.49 \pm 0.016$ \\
\hline & 9 & 6 & 4 & 1 & 2 & 7 & $0.51 \pm 0.016$ \\
\hline & $\dagger 10$ & 6 & 4 & 2 & 1 & 7 & $0.14 \pm 0.011$ \\
\hline & $* 11$ & 6 & 4 & 4 & 0 & 8 & $0.08 \pm 0.0086$ \\
\hline \multirow[t]{2}{*}{$4 \mathrm{~d}$} & 1 & 4 & 6 & 0 & 3 & 9 & $0.50 \pm 0.016$ \\
\hline & 2 & 4 & 6 & 0 & 3 & 9 & $0.50 \pm 0.016$ \\
\hline \multirow{12}{*}{$4 \mathrm{f}$} & 2 & 2 & 8 & 0 & 4 & 12 & $1.0 \pm 0.00071$ \\
\hline & 3 & 2 & 8 & 0 & 4 & 12 & $1.0 \pm 0.00071$ \\
\hline & 4 & 2 & 8 & 0 & 4 & 12 & $1.0 \pm 0.00071$ \\
\hline & 5 & 4 & 6 & 1 & 3 & 12 & $0.89 \pm 0.010$ \\
\hline & 6 & 4 & 6 & 1 & 3 & 10 & $0.88 \pm 0.010$ \\
\hline & 7 & 2 & 8 & 0 & 4 & 12 & $1.0 \pm 0.00071$ \\
\hline & 8 & 2 & 8 & 0 & 4 & 12 & $1.0 \pm 0.00071$ \\
\hline & 9 & 4 & 6 & 1 & 3 & 10 & $0.89 \pm 0.001$ \\
\hline & 10 & 6 & 4 & 4 & 1 & 9 & $0.31 \pm 0.015$ \\
\hline & $\dagger 11$ & 6 & 4 & 2 & 2 & 8 & $0.61 \pm 0.015$ \\
\hline & 12 & 6 & 4 & 2 & 2 & 8 & $0.64 \pm 0.015$ \\
\hline & $* 13$ & 6 & 4 & 8 & 0 & 12 & $0.27 \pm 0.014$ \\
\hline $4 \mathrm{~g}$ & $\dagger 1$ & 8 & 2 & 0 & 1 & 3 & $0.033 \pm 0.0056$ \\
\hline $4 \mathrm{~h}$ & 8 & 4 & 6 & 1 & 3 & 10 & $0.91 \pm 0.0090$ \\
\hline
\end{tabular}




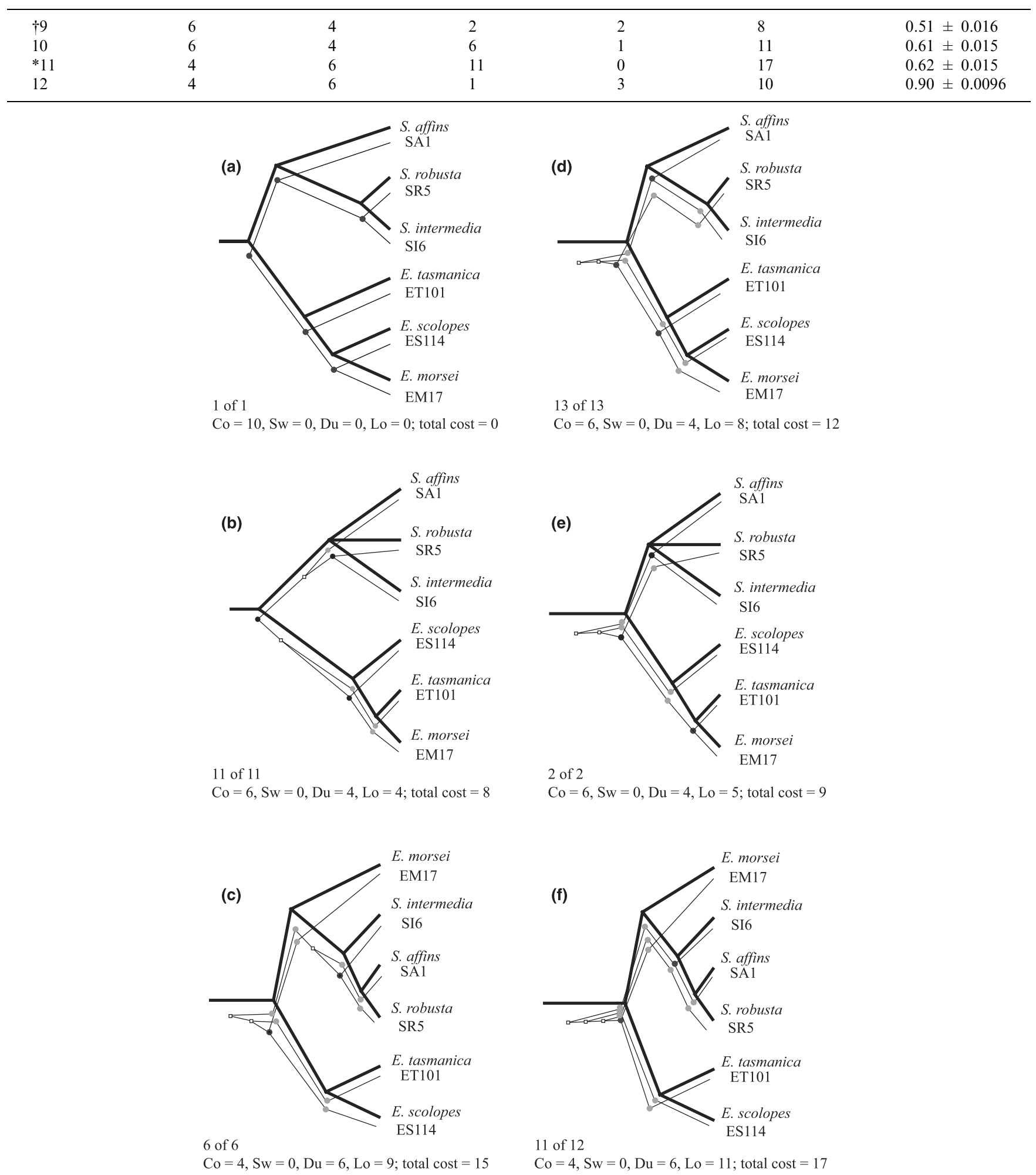

Fig. 7. Analysis of codivergence between $V$. fischeri strains and sepiolid squids. Reconciled trees shown here represent the jungles requiring no host switches (Sw) for the following analyses: (a) Reported symbiont phylogeny of Nishiguchi et al. (1998) reconciled with host squid ITS phylogeny; (b) reported symbiont phylogeny of Nishiguchi et al. (1998) reconciled with host squid COI phylogeny; (c) reported symbiont phylogeny of Nishiguchi et al. (1998) reconciled with host squid phylogeny of Nishiguchi et al. (2004); (d) reanalyzed symbiont phylogeny reconciled with host squid squid ITS phylogeny of Nishiguchi et al. (1998); (e) reanalyzed symbiont phylogeny reconciled with host squid squid COI phylogeny of Nishiguchi et al. (1998); (f) reanalyzed symbiont phylogeny reconciled with host squid squid phylogeny of Nishiguchi et al. (2004). Host trees are in heavy lines, and associate trees are in light lines. Black circles represent codivergent events (Co), white circles or squares represent duplications ( Du), and gray circles represent loss (Lo). 


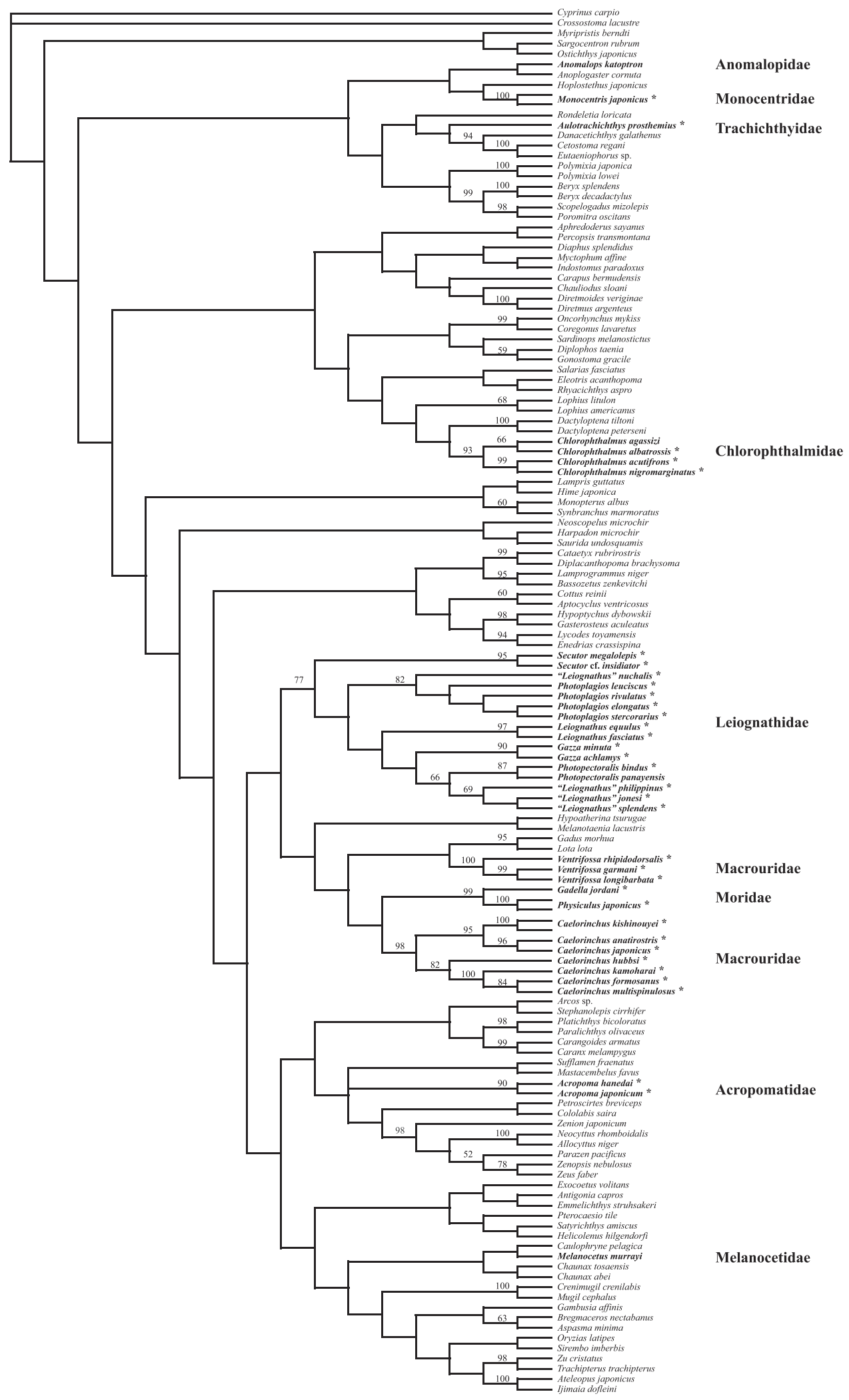

Fig. 8. Phylogeny of fishes based on mitochondrial COI sequence data. Fish families with bacterially luminous members are indicated by the family name to the right of species names. Species with bacterial light organs are in bold type; specimens that appear in Fig. 2 or Fig. 3 are marked with an asterisk. Jackknife values appear at nodes. 


\section{Appendix D: Analysis of fish COI sequence data}

This appendix presents a phylogeny for a more thorough sampling of fishes, to place our analyses of bacterially bioluminescent fishes in a larger phylogenetic context. The tree (Fig. 8) demonstrates that bioluminescent symbioses, fishes with light organs colonized by luminous bacteria, have evolved multiple times. Sequence data for all species were either obtained in this laboratory (see Materials and methods and Appendix A) or were obtained from GenBank, using the data of Miya et al. (2003). Sequences were aligned by inferred amino acid sequence. The final data matrix consisted of 136 taxa and 1587 characters, 708 of which were parsimony informative. Approximately 50 bases at the $3^{\prime}$ end of the aligned matrix were excluded because of alignment difficulties. The analysis was performed in TNT using the following strategy: an initial run used a combination of TBR, tree drifting, tree fusing, and sectorial searches $(x m u l t=$ level 8$)$; the single tree was then subjected to the parsimony ratchet $($ ratchet $=$ iter 1000), which saved five shorter trees; the five trees were then checked with drifting (drift $=$ iter 1000) which saved no additional trees; and the five trees were then subjected to further ratcheting (ratchet $=$ iter 10000). Two trees resulted (length $=18520, \mathrm{CI}=0.08, \mathrm{RI}=0.34$ ), the consensus of which is shown here (Fig. 8). Optimization of the presence of the light organ demonstrates that the bacterial light organ either arose independently nine times (DELTRAN) or arose seven times and was lost twice (ACCTRAN). 